\title{
The potential distributions, and estimated spatial requirements and population sizes, of the medium to large-sized mammals in the planning domain of the Greater Addo Elephant National Park project
}

\author{
A.F. Boshoff, G.I.H. KerLey, R.M. CoWLING and S.L. WiLson
}

Boshoff, A.F., G.I.H. Kerley, R.M. Cowling and S.L. Wilson. 2002. The potential distributions, and estimated spatial requirements and population sizes, of the medium to large-sized mammals in the planning domain of the Greater Addo Elephant National Park project. Koedoe 45(2): 85-116. Pretoria. ISSN 0075-6458.

The Greater Addo Elephant National Park project (GAENP) involves the establishment of a mega biodiversity reserve in the Eastern Cape, South Africa. Conservation planning in the GAENP planning domain requires systematic information on the potential distributions and estimated spatial requirements, and population sizes of the medium to largesized mammals. The potential distribution of each species is based on a combination of literature survey, a review of their ecological requirements, and consultation with conservation scientists and managers. Spatial requirements were estimated within $21 \mathrm{Mam}-$ mal Habitat Classes derived from 43 Land Classes delineated by expert-based vegetation and river mapping procedures. These estimates were derived from spreadsheet models based on forage availability estimates and the metabolic requirements of the respective mammal species, and that incorporate modifications of the agriculture-based Large Stock Unit approach. The potential population size of each species was calculated by multiplying its density estimate with the area of suitable habitat. Population sizes were calculated for pristine, or near pristine, habitats alone, and then for these habitats together with potentially restorable habitats for two park planning domain scenarios. These data will enable (a) the measurement of the effectiveness of the GAENP in achieving predetermined demographic, genetic and evolutionary targets for mammals that can potentially occur in selected park sizes and configurations, (b) decisions regarding acquisition of additional land to achieve these targets to be informed, (c) the identification of species for which targets can only be met through metapopulation management, (d) park managers to be guided regarding the re-introduction of appropriate species, and (e) the application of realistic stocking rates. Where possible, the model predictions were tested by comparison with empirical data, which in general corroborated the predictions. All estimates should be considered as testable hypotheses.

Key words: conservation planning, mammals, distribution, density, population estimates, Addo, South Africa.

A.F. Boshoff, G.I.H. Kerley and S.L. Wilson, Terrestrial Ecology Research Unit, Department of Zoology, University of Port Elizabeth, Port Elizabeth, 6013, Republic of South Africa; R.M. Cowling, Terrestrial Ecology Research Unit, Department of Botany, University of Port Elizabeth, Port Elizabeth, 6013, Republic of South Africa.

\section{Introduction}

In November 2000, the Global Environment Facility (GEF) approved a grant to South African National Parks (SANParks) to research and prepare a full proposal to the GEF for the planning and establishment of a "greater" Addo Elephant National Park (GAENP). The SW boundary of the Addo Elephant National Park (AENP) is some $35 \mathrm{~km}$ east of the city of Port Elizabeth

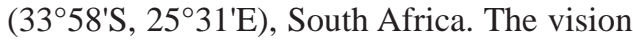
for an expanded Addo Elephant National 
Park was developed and documented by Kerley \& Boshoff (1997, 2002, www.zoo. upe.ac.za/teru). Systematic conservation planning forms an integral and critical component of the implementation of the GAENP project, managed by South African National Parks ("http://www.addoelephantpark.com" www.addoelephantpark.com). Note that the original boundary of the proposed expansion to the AENP (Kerley \& Boshoff 1997) has been modified, by SANParks, for the purposes of the conservation planning exercise for GAENP, by the addition of a 5-km buffer that follows cadastral boundaries.

While the impressive plant diversity remains a major focus of conservation planning in the establishment of a GAENP (Kerley \& Boshoff 1997), other biota and ecological processes which impact on the park's biodiversity must be taken into account in attempting to achieve its broad conservation objectives. The species' patterns and ecological and evolutionary processes in the GAENP planning domain include the medium to large-sized mammals and the processes that they drive, many of which (a) are in need of conservation intervention, and (b) may have an important impact on the park's biota, at the species, community and ecosystem functioning levels. Herbivory is known to have an impact on the species composition, structure and dynamics of fynbos vegetation (Campbell 1986; Johnson 1992) and thicket vegetation (Barratt \& Hall-Martin 1991; Johnson et al. 1999; Lombard et al. 2001; Moolman \& Cowling 1994; Penzhorn et al. 1974; Stuart-Hill 1992; Stuart-Hill \& Aucamp 1993). The important role that the proposed mega reserve will play in conserving a diverse array of larger mammals, including the top predators and a number of megaherbivores, is emphasised by Kerley \& Boshoff (1997). The numerous ecological processes that are mediated by the larger mammals, or that they participate in, are reported on elsewhere (Boshoff et al. 2001a).

The medium to large-sized mammals were selected as "target" species (sensu Wilcox 1982) for the GAENP planning exercise because it is likely that if their minimum area requirements are met, adequate survival conditions will be simultaneously met for other biota. In this regard, many of these mammals qualify as "umbrella" species (sensu Wilcox 1982) since their minimum area requirements are likely to be at least as comprehensive as those for the remainder of the community. Mammals with a large body size (e.g., some ungulates) or which occupy a high trophic level (e.g., carnivores) are regarded as good candidates for target species acting as "umbrella" species (Wilcox 1982). In addition, the distributions and spatial requirements/densities of the larger mammals are probably better known, or can be better estimated, than those of the smallsized mammals in the GAENP planning domain. In any case, realistic data for these two population parameters are essential for any conservation exercise that deals with the establishment and maintenance of minimum viable populations of the larger mammalian fauna (Caughley 1994; Caughley \& Sinclair 1994; Lande \& Barrowclough 1987).

An additional consideration for determining minimum area requirements for preserving biological diversity is that of the estimation of minimum viable populations (MVP) for “target” species (Wilcox 1982; Soulé 1987). The MVP is a set of specifications concerning the size and structure of the populations of a species that is necessary to provide a margin of safety from extinction. The MVP for a species can be translated into the minimum area requirements by determining the amount and type of habitat that will satisfy the MVP. In view of this, it is necessary for realistic estimates of the spatial requirements/densities of each the selected species in the GAENP planning domain to be obtained.

In summary, systematic data and information are required to enable conservation planners to calculate the potential numbers of individuals of each mammal species, within the mammal habitats within various park configuration scenarios. These data will enable planners to measure the effectiveness of the proposed GAENP in achieving predeter- 
mined demographic, genetic and evolutionary targets for medium to large-sized mammals that can potentially occur in the park. In addition, they will inform decisions regarding acquisition of additional land, where necessary, to achieve these targets, and help identify species for which targets can only be met through metapopulation management.

\section{Approach}

The indigenous mammal species included in this study (Table 1) are those with a mass greater than ca. $2 \mathrm{~kg}$ (cf. Chew 1978), that are the most prominent on the landscape, and which are generally amenable to direct management. As part of a separate exercise, 43 Land Classes were delineated through field mapping by Kruger \& Sykes (2002), using as a basis the hierarchical classification of Subtropical Thicket by Vlok \& EustonBrown (2002). It was considered impractical to use this detailed classification for deriving the potential distributions and estimated spatial requirements/densities of the larger mammals. It was consequently decided to collapse the 43 Land Classes into a practical number (21) of Mammal Habitat Classes (MHCs) and to use these as the biodiversity surrogates for the mammal conservation planning component of the Greater Addo Elephant National Park. Only those Land Classes that exhibited a generally high degree of similarity, in terms of vegetation structure (and hence mammal habitat) and productivity (determining mammal densities), and for which any differences that exist are considered unlikely to impact significantly on the known and potential presence and densities of mammal species, were combined. The potential distributions and estimated spatial requirements of the two otter species are based exclusively on aquatic habitats, i.e., coastline and rivers, where appropriate.

\section{DisTRIBUTIONS}

\section{Methods}

Two steps were followed in determining the potential distribution of each species, within each MHC in the GAENP planning domain.

\section{Collation and interpretation of evidence} that a species occurred, or could potentially occur in all, or in a specific part, of the GAENP planning domain.

The early and recent published literature was consulted, as were conservation scientists and managers with a good knowledge of the macro fauna of the existing Addo Elephant National Park (AENP) and close environs (see Boshoff \& Kerley 2001 and Boshoff et al. 2001b for details of the methods used). The mammal checklist for the AENP was also consulted, as were the mammal collection registers of the Amatole Museum in King William's Town, where the terrestrial mammal collections from the four provincial museums in the Eastern Cape are now housed.

The present study attempts to reconstruct the distributions of indigenous herbivores in the period prior to arrival of European settlers, in the GAENP planning domain, in the mid $17^{\text {th }}$ century. These distributions thus represent a situation where the patterns and processes exhibited by the mammals of the region were presumably still fairly intact. Thus, domestic herbivores, maintained by Khoi pastoralists in the period prior to European settlement, have not been taken into account in this analysis, owing to a lack of information on their distributions, nomadic movements and densities.

Zoological and explorer's records from the $17^{\text {th }}, 18^{\text {th }}$ and $19^{\text {th }}$ centuries have been well reviewed by Du Plessis (1969), Rookmaaker (1989) and Skead (1987). These reviews were useful in determining the general presence or absence of most species in all or parts of the GAENP planning domain, but they generally proved to be vague in terms of the exact areas and habitats occupied by the various species. This resulted mainly from the fact that most early hunters and naturalists only recorded mammal occurrences along well travelled, or passable, routes, and few travelled at night, thereby missing the nocturnal species. Other problems arose with interpreting the early, published accounts with regard to the accurate identification of some species (see Skead 1987). 
The following additional sources were consulted for information on the historical occurrence of mammals in the broader area around the GAENP: Coetzee (1979); Hewitt (1931); Lloyd \& Millar (1983); Shortridge (1942); Skinner \& Smithers (1990); Smithers (1986); Stuart (1981); Stuart (1985); Stuart et al. (1985).

A review of the recent (20 th century) literature revealed that surveys are incomplete in terms of species and/or area covered and tend to use political boundaries rather than ecological zones as the basic mapping units. The scale of the distribution maps in the standard account of the mammals in the southern African sub-region (Skinner \& Smithers 1990) allows only generalised ranges (extents of occurrence) to be determined. Similarly, distributions of threatened mammal species are illustrated on a broad regional basis (Smithers 1986). Museum specimens and records provide useful point data but are biased in that they only provide "presence" data, i.e., they do not represent the results of systematic data collection throughout the GAENP planning domain, and they do not take into account the possible migratory or nomadic patterns of some species.

\section{Estimation of potential presence of the species, based on their ecological requirements}

The potential presence/absence of each species in each MHC was determined according to our understanding of their ecological requirements, including a review of published habitat requirements (in the general GAENP area and further afield), our personal field knowledge, and the respective habitat characteristics of each MHC. These characteristics included dominant plant species, vegetation structure, grass component, soil nutrients, geology, topography, modal altitude, mean rainfall and rainfall seasonality). See Boshoff \& Kerley (2001) and Boshoff et al. (2001b) for details of the methods used. As part of this exercise, AENP conservation scientists and managers, with ecological knowledge of mammals of the area, were consulted.

The potential distribution of each species is presented according to three categories:

- MHCs with the potential to sustain significant resident (i.e., present all year round and breeding) populations. In these MHCs the animals are generally homogeneously distributed across the landscape;

- MHCs which may be used on a seasonal basis, or which may carry small populations in habitat refugia (i.e., patchy basis). In these MHCs the animals are generally not homogeneously dis- tributed, temporally and spatially, across the landscape;

- MHCs where the species is unlikely to occur, except perhaps for vagrants or during rare and short incursions. In such cases the species was considered to be absent, and the MHC in question could not be relied upon to contribute to the conservation of that species.

The hippopotamus potentially occurs, in suitable habitat, in and along major rivers and dams. These waterbodies must be perennial in nature and must contain pools at least $1.5 \mathrm{~m}$ deep. The distance travelled from watercourses to feeding grounds depends on forage availability and can vary widely. Hippopotamus generally forage within about $1.5 \mathrm{~km}$ from waterbodies but will move freely up to eight or $10 \mathrm{~km}$, and are known to move much further when forage is scarce (Skinner \& Smithers 1990). Potential hippopotamus habitat was marked on a digital terrain map produced by CSIR-Environmentek. For practical reasons, the overall distribution of this species is presented, rather than its distribution according to Mammal Habitat Class. Using GIS, those parts of MHCs that overlap with potential hippopotamus habitat are considered as additional (i.e., additional to the original 21 MHCs) MHCs and are treated as such for the calculation of estimated spatial requirements and densities (see "Spatial Requirements”).

The potential distributions (that are linear in nature) of the two otter species were marked on a digital terrain map that identifies the major rivers and dams. A conservative approach was adopted in determining these distributions; only waterbodies that can be confidently classified as being perennial were included.

The approach described above, which involves a simple model based on the estimated range of each species and its association with mappable environmental features expressed as a series of polygons, is broadly similar to that used in other studies (e.g., Butterfield et al. 1994).

\section{Results}

Of the 44 indigenous, non-marine mammal species that occur, or can potentially occur in the proposed GAENP (Table 1), 41 species occur exclusively in terrestrial habitats, whereas three species, the Cape clawless and spotted-necked otters and the hippopotamus are associated with aquatic habitats. Three species are omnivores, 18 are carnivores and 23 are herbivores. Of the 44 species, 35 are 
Table 1

The common and scientific names, foraging guild classifications and current (2001) presence of potentially occurring medium- to large-sized omnivorous, carnivorous and herbivorous mammals in the GAENP planning domain. $P$ = Present in 2001. Taxonomic order (except for aardvark - see text) and nomenclature (scientific and common names) follow Skinner \& Smithers (1990)

\begin{tabular}{|c|c|c|c|}
\hline Common name & Scientific name & Foraging guild & Presence in 2001 \\
\hline \multicolumn{4}{|l|}{ OMNIVORES } \\
\hline Chacma baboon & Papio cynocephalus & & $\mathrm{P}$ \\
\hline Vervet monkey & Cercopithecus aethiops & & $\mathrm{P}$ \\
\hline Porcupine & Hystrix africaeaustralis & & $\mathrm{P}$ \\
\hline Aardvark & Orycteropus afer & & $\mathrm{P}$ \\
\hline \multicolumn{4}{|l|}{ CARNIVORES } \\
\hline Aardwolf & Proteles cristatus & & $\mathrm{P}$ \\
\hline Brown hyaena & Hyaenna brunnea & & \\
\hline Spotted hyaena & Crocuta crocuta & & \\
\hline Cheetah & Acinonyx jubatus & & \\
\hline Leopard & Panthera pardus & & $\mathrm{P}$ \\
\hline Lion & Panthera leo & & \\
\hline Caracal & Felis caracal & & $\mathrm{P}$ \\
\hline African wild cat & Felis lybica & & $\mathrm{P}$ \\
\hline Small spotted cat & Felis nigripes & & $\mathrm{P}$ \\
\hline Serval & Felis serval & & \\
\hline Bat-eared fox & Otocyon megalotis & & $\mathrm{P}$ \\
\hline Wild dog & Lycaon pictus & & \\
\hline Cape fox & Vulpes chama & & $\mathrm{P}$ \\
\hline Black-backed jackal & Canis mesomelas & & $\mathrm{P}$ \\
\hline Cape clawless otter & Aonyx capensis & & $\mathrm{P}$ \\
\hline Spotted-necked otter & Lutra maculicollis & & $\mathrm{P}$ \\
\hline Honey badger & Mellivora capensis & & $\mathrm{P}$ \\
\hline \multicolumn{4}{|l|}{ HERBIVORES } \\
\hline African elephant & Loxodonta africana & Mixed feeder & $\mathrm{P}$ \\
\hline Black rhinoceros & Diceros bicornis & Browser & $\mathrm{P}$ \\
\hline Cape mountain zebra & Equus zebra zebra & Bulk grazer & $\mathrm{P}$ \\
\hline Burchell's zebra & Equus burchelli & Bulk grazer & $\mathrm{P}$ \\
\hline Bushpig & Potamochoerus porcus & Mixed feeder & $\mathrm{P}$ \\
\hline Warthog & Phacochoerus aethiopicus & Concentrate grazer & $\mathrm{P}$ \\
\hline Hippopotamus & Hippopotamus amphibius & Bulk grazer & $\mathrm{P}$ \\
\hline Black wildebeest & Connochaetes gnou & Concentrate grazer & \\
\hline Red hartebeest & Alcelaphus buselaphus & Concentrate grazer & $\mathrm{P}$ \\
\hline Blue duiker & Philantomba monticola & Browser & $\mathrm{P}$ \\
\hline Common duiker & Sylvicapra grimmia & Browser & $\mathrm{P}$ \\
\hline Springbok & Antidorcas marsupialis & Mixed feeder & $\mathrm{P}$ \\
\hline Klipspringer & Oreotragus oreotragus & Browser & $\mathrm{P}$ \\
\hline Oribi & Ourebia ourebi & Concentrate grazer & \\
\hline Steenbok & Raphicerus campestris & Browser & $\mathrm{P}$ \\
\hline Grysbok & Raphicerus melanotis & Browser & $\mathrm{P}$ \\
\hline Grey rhebok & Pelea capreolus & Concentrate grazer & $\mathrm{P}$ \\
\hline African buffalo & Syncerus caffer & Bulk grazer & $\mathrm{P}$ \\
\hline Kudu & Tragelaphus strepsiceros & Browser & $\mathrm{P}$ \\
\hline Bushbuck & Tragelaphus scriptus & Browser & $\mathrm{P}$ \\
\hline Eland & Taurotragus oryx & Mixed feeder & $\mathrm{P}$ \\
\hline Reedbuck & Redunca arundinum & Concentrate grazer & \\
\hline Mountain reedbuck & Redunca fulvorufula & Concentrate grazer & $\mathrm{P}$ \\
\hline
\end{tabular}


already present and nine could be considered for re-introduction.

The 21 MHCs delineated for this study are mapped in Fig. 1 and listed in Table 2. The potential occurrence of each species in each MHC, on a "resident" or "seasonal/patchy" basis (Table 2), is illustrated in a series of distribution maps (Figs. 2-44). Due to a lack of detailed habitat information, the hippopotamus and the two otter species are considered to be potentially resident in all habitats mapped for these species.

\section{Discussion}

Notwithstanding the constraints inherent in the approach used here, the maps provided in this report are considered to represent realistic potential distributions of the medium to large-sized mammals in the GAENP planning domain. We stress, however, that these data are underpinned by putative habitatmammal relationships that are testable in the future. Nonetheless, the data provide new information that is essential for effective conservation planning in the GAENP, and for developing a greater understanding of the larger terrestrial vertebrates as indicators of environmental change in the proposed park (Macdonald 1992).

The black wildebeest is the only species for which the greater part of its distribution range within the GAENP planning domain falls within the 5-km buffer zone. For two other species, namely oribi and reedbuck, a significant proportion of their distribution range within the planning domain falls within the 5-km buffer.

It is emphasised that the allocation of species to specific MHCs should not be interpreted to imply that the distributions of the mammals are spatially and temporally fixed in the planning domain. Because of the dearth of ecological information from the region, any reconstruction of the demographics and dynamics of the medium to large mammal populations must be based on the collection of new information.
Owing, in part, to the expansion of the AENP, there are currently seven extralimital species in the park, namely gemsbok Oryx gazella, impala Aepyceros melampus, waterbuck Kobus ellipsiprymnus, blesbok Damaliscus dorcas phillipsi, blue wildebeest Connochaetes taurinus, red lechwe Kobus leche and nyala Tragelaphus angasii. It is recommended that these species be removed from the AENP, in view of the real and potential ecological and economic costs of keeping them in the park (Castley et al. 2001).

\section{SPATIAL REQUIREMENTS}

\section{Methods}

The estimated spatial requirements of each species, and the associated density estimates, refer exclusively to those MHCs in the GAENP planning domain where the species is likely to occur, on a "resident" or "seasonal/patchy" basis.

\section{Omnivores and carnivores}

The overall lack of information from the GAENP domain precluded an estimation of the spatial requirements of the omnivores and carnivores according to individual Mammal Habitat Classes. Consequently, the planning domain was treated as a homogeneous unit for this purpose. This is likely to be more appropriate for the smaller species than for the larger ones; the abundance of the latter will generally reflect the abundance and spatial distribution of the larger herbivores.

Estimates of the spatial requirements of each species in each MHC were based on a review of available information on densities, social structures, breeding units, territory sizes and home ranges. However, since published ecological information for the region is not available (cf. Boshoff et al. 2001b) for any of the species that can potentially occur there, estimates based on the interpretation and extrapolation of information on the relevant species from other regions in South Africa, mainly the Nama-Karoo, Grassland and Savanna biomes (sensu Low \& Rebelo 1996), were used as surrogates. In the case of the carnivores (especially the large predators and scavengers such as lion and spotted hyaena) the assumption is made that predator-prey systems are in operation and that sufficient food is available. For the sake 
Table 2

The presence/absence of the medium- to large-sized mammals in the GAENP planning domain, according to Mammal Habitat Class ( $R=$ Resident, $S P=$ Seasonal/Patchy)

\begin{tabular}{|c|c|c|c|c|c|c|c|c|c|c|c|c|c|c|c|c|c|c|c|c|c|}
\hline \multirow[t]{2}{*}{ Common name } & \multicolumn{21}{|c|}{ Mammal Habitat Class } \\
\hline & 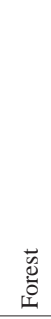 & 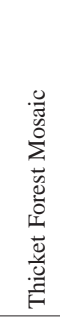 & 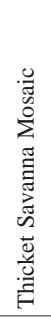 & 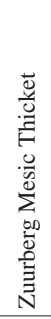 & 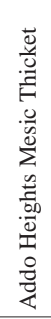 & 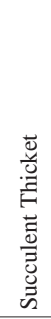 & 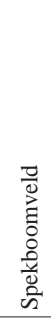 & 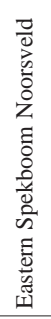 & 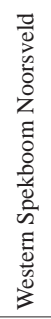 & 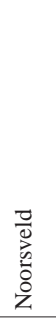 & 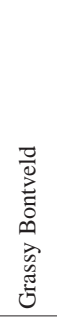 & 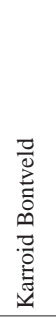 & 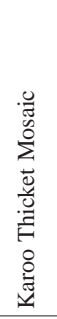 & 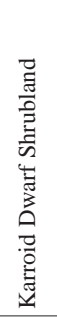 & 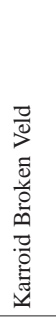 & 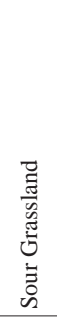 & 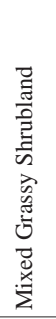 & $\begin{array}{l}\text { o } \\
\text { 站 }\end{array}$ & 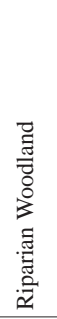 & 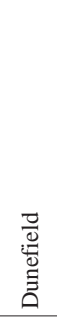 & 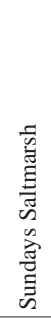 \\
\hline Chacma baboon & & & & $\mathrm{R}$ & & $\mathrm{R}$ & & $\mathrm{R}$ & $\mathrm{R}$ & $\mathrm{R}$ & & & $\mathrm{R}$ & SP & $\mathrm{R}$ & $\mathrm{R}$ & $\mathrm{R}$ & $\mathrm{R}$ & $\mathrm{R}$ & & \\
\hline Vervet monkey & $\mathrm{R}$ & $\mathrm{R}$ & $\mathrm{R}$ & $\mathrm{R}$ & $\mathrm{R}$ & $\mathrm{R}$ & $\mathrm{R}$ & $\mathrm{R}$ & $\mathrm{R}$ & SP & SP & SP & $\mathrm{R}$ & SP & SP & & & & $\mathrm{R}$ & SP & \\
\hline Porcupine & $\mathrm{R}$ & $\mathrm{R}$ & $\mathrm{R}$ & $\mathrm{R}$ & $\mathrm{R}$ & $\mathrm{R}$ & $\mathrm{R}$ & $\mathrm{R}$ & $\mathrm{R}$ & $\mathrm{R}$ & $\mathrm{R}$ & $\mathrm{R}$ & $\mathrm{R}$ & $\mathrm{R}$ & $\mathrm{R}$ & $\mathrm{R}$ & $\mathrm{R}$ & $\mathrm{R}$ & $\mathrm{R}$ & SP & \\
\hline Aardwolf & & & SP & SP & SP & SP & SP & SP & SP & SP & $\mathrm{R}$ & $\mathrm{R}$ & $\mathrm{R}$ & $\mathrm{R}$ & $\mathrm{R}$ & $\mathrm{R}$ & $\mathrm{R}$ & SP & SP & & \\
\hline Brown hyaena & & SP & $\mathrm{R}$ & $\mathrm{R}$ & $\mathrm{R}$ & $\mathrm{R}$ & $\mathrm{R}$ & $\mathrm{R}$ & $\mathrm{R}$ & $\mathrm{R}$ & $\mathrm{R}$ & $\mathrm{R}$ & $\mathrm{R}$ & $\mathrm{R}$ & $\mathrm{R}$ & $\mathrm{R}$ & $\mathrm{R}$ & $\mathrm{R}$ & $\mathrm{R}$ & $\mathrm{R}$ & SP \\
\hline Spotted hyaena & & & SP & SP & SP & SP & SP & $\mathrm{R}$ & $\mathrm{R}$ & $\mathrm{R}$ & $\mathrm{R}$ & $\mathrm{R}$ & $\mathrm{R}$ & $\mathrm{R}$ & $\mathrm{R}$ & SP & $\mathrm{R}$ & SP & $\mathrm{R}$ & SP & SP \\
\hline Cheetah & & & & & & & & $\mathrm{R}$ & $\mathrm{R}$ & $\mathrm{R}$ & & & & $\mathrm{R}$ & $\mathrm{R}$ & & & & & & \\
\hline Leopard & $\mathrm{R}$ & $\mathrm{R}$ & $\mathrm{R}$ & $\mathrm{R}$ & $\mathrm{R}$ & $\mathrm{R}$ & $\mathrm{R}$ & $\mathrm{R}$ & $\mathrm{R}$ & $\mathrm{R}$ & $\mathrm{R}$ & $\mathrm{R}$ & $\mathrm{R}$ & $\mathrm{R}$ & $\mathrm{R}$ & $\mathrm{R}$ & $\mathrm{R}$ & $\mathrm{R}$ & $\mathrm{R}$ & SP & SP \\
\hline Lion & & & $\mathrm{R}$ & SP & SP & $\mathrm{R}$ & SP & $\mathrm{R}$ & $\mathrm{R}$ & $\mathrm{R}$ & $\mathrm{R}$ & $\mathrm{R}$ & $\mathrm{R}$ & $\mathrm{R}$ & $\mathrm{R}$ & SP & $\mathrm{R}$ & SP & $\mathrm{R}$ & SP & SP \\
\hline Caracal & SP & SP & $\mathrm{R}$ & $\mathrm{R}$ & $\mathrm{R}$ & $\mathrm{R}$ & $\mathrm{R}$ & $\mathrm{R}$ & $\mathrm{R}$ & $\mathrm{R}$ & $\mathrm{R}$ & $\mathrm{R}$ & $\mathrm{R}$ & $\mathrm{R}$ & $\mathrm{R}$ & SP & $\mathrm{R}$ & SP & $\mathrm{R}$ & SP & SP \\
\hline African wild cat & & SP & $\mathrm{R}$ & $\mathrm{R}$ & $\mathrm{R}$ & $\mathrm{R}$ & $\mathrm{R}$ & $\mathrm{R}$ & $\mathrm{R}$ & $\mathrm{R}$ & $\mathrm{R}$ & $\mathrm{R}$ & $\mathrm{R}$ & $\mathrm{R}$ & $\mathrm{R}$ & SP & $\mathrm{R}$ & SP & $\mathrm{R}$ & SP & SP \\
\hline Small spotted cat & & & & & & SP & & $\mathrm{R}$ & $\mathrm{R}$ & $\mathrm{R}$ & $\mathrm{R}$ & $\mathrm{R}$ & $\mathrm{R}$ & $\mathrm{R}$ & $\mathrm{R}$ & & $\mathrm{R}$ & & & & \\
\hline Serval & & & SP & & & SP & & SP & SP & & SP & & SP & & & & SP & SP & $\mathrm{R}$ & & \\
\hline Bat-eared fox & & & SP & & & SP & SP & $\mathrm{R}$ & $\mathrm{R}$ & $\mathrm{R}$ & $\mathrm{R}$ & $\mathrm{R}$ & $\mathrm{R}$ & $\mathrm{R}$ & $\mathrm{R}$ & & SP & & SP & & \\
\hline Wild dog & & & $\mathrm{R}$ & $\mathrm{R}$ & $\mathrm{R}$ & $\mathrm{R}$ & $\mathrm{R}$ & $\mathrm{R}$ & $\mathrm{R}$ & $\mathrm{R}$ & $\mathrm{R}$ & $\mathrm{R}$ & $\mathrm{R}$ & $\mathrm{R}$ & $\mathrm{R}$ & SP & $\mathrm{R}$ & SP & $\mathrm{R}$ & SP & SP \\
\hline Cape fox & & & & & & SP & SP & $\mathrm{R}$ & $\mathrm{R}$ & $\mathrm{R}$ & $\mathrm{R}$ & $\mathrm{R}$ & $\mathrm{R}$ & $\mathrm{R}$ & $\mathrm{R}$ & & SP & & SP & & \\
\hline $\begin{array}{l}\text { Black-backed } \\
\text { jackal }\end{array}$ & SP & $\mathrm{R}$ & $\mathrm{R}$ & $\mathrm{R}$ & $\mathrm{R}$ & $\mathrm{R}$ & $\mathrm{R}$ & $\mathrm{R}$ & $\mathrm{R}$ & $\mathrm{R}$ & $\mathrm{R}$ & $\mathrm{R}$ & $\mathrm{R}$ & $\mathrm{R}$ & $\mathrm{R}$ & SP & $\mathrm{R}$ & SP & $\mathrm{R}$ & SP & SP \\
\hline Honey badger & SP & SP & $\mathrm{R}$ & $\mathrm{R}$ & $\mathrm{R}$ & $\mathrm{R}$ & $\mathrm{R}$ & $\mathrm{R}$ & $\mathrm{R}$ & $\mathrm{R}$ & $\mathrm{R}$ & $\mathrm{R}$ & $\mathrm{R}$ & $\mathrm{R}$ & $\mathrm{R}$ & $\mathrm{R}$ & $\mathrm{R}$ & $\mathrm{R}$ & $\mathrm{R}$ & SP & SP \\
\hline Aardvark & & & $\mathrm{R}$ & SP & SP & $\mathrm{R}$ & $\mathrm{R}$ & $\mathrm{R}$ & $\mathrm{R}$ & $\mathrm{R}$ & $\mathrm{R}$ & $\mathrm{R}$ & $\mathrm{R}$ & $\mathrm{R}$ & $\mathrm{R}$ & SP & $\mathrm{R}$ & & $\mathrm{R}$ & & \\
\hline African elephant & SP & $\mathrm{R}$ & $\mathrm{R}$ & $\mathrm{R}$ & $\mathrm{R}$ & $\mathrm{R}$ & $\mathrm{R}$ & SP & SP & SP & $\mathrm{R}$ & $\mathrm{R}$ & $\mathrm{R}$ & SP & SP & & SP & & $\mathrm{R}$ & & \\
\hline Black rhinoceros & & SP & $\mathrm{R}$ & $\mathrm{R}$ & $\mathrm{R}$ & $\mathrm{R}$ & $\mathrm{R}$ & $\mathrm{R}$ & $\mathrm{R}$ & $\mathrm{R}$ & $\mathrm{R}$ & $\mathrm{R}$ & $\mathrm{R}$ & $\mathrm{R}$ & $\mathrm{R}$ & & $\mathrm{R}$ & & $\mathrm{R}$ & & \\
\hline Mountain zebra & & & & SP & & SP & & SP & SP & SP & & & SP & SP & SP & $\mathrm{R}$ & $\mathrm{R}$ & $\mathrm{R}$ & & & \\
\hline Plains zebra & & & SP & & SP & & SP & $\mathrm{R}$ & $\mathrm{R}$ & $\mathrm{R}$ & $\mathrm{R}$ & $\mathrm{R}$ & & $\mathrm{R}$ & $\mathrm{R}$ & & & & SP & & \\
\hline Bushpig & $\mathrm{R}$ & $\mathrm{R}$ & SP & $\mathrm{R}$ & $\mathrm{R}$ & $\mathrm{R}$ & $\mathrm{R}$ & & & & SP & SP & SP & & & & & & $\mathrm{R}$ & SP & \\
\hline Warthog & & & SP & & SP & SP & SP & $\mathrm{R}$ & $\mathrm{R}$ & $\mathrm{R}$ & $\mathrm{R}$ & $\mathrm{R}$ & SP & $\mathrm{R}$ & $\mathrm{R}$ & & & & $\mathrm{R}$ & & \\
\hline Black wildebeest & & & & & & & & SP & & & & & & & SP & & & & & & \\
\hline Red hartebeest & & & SP & & & SP & & $\mathrm{R}$ & $\mathrm{R}$ & $\mathrm{R}$ & $\mathrm{R}$ & $\mathrm{R}$ & SP & $\mathrm{R}$ & $\mathrm{R}$ & SP & $\mathrm{R}$ & SP & SP & & \\
\hline Blue duiker & $\mathrm{R}$ & $\mathrm{R}$ & SP & $\mathrm{R}$ & $\mathrm{R}$ & SP & SP & & & & & & & & & & & & SP & & \\
\hline Common duiker & SP & SP & $\mathrm{R}$ & $\mathrm{R}$ & $\mathrm{R}$ & $\mathrm{R}$ & $\mathrm{R}$ & $\mathrm{R}$ & $\mathrm{R}$ & $\mathrm{R}$ & SP & SP & $\mathrm{R}$ & SP & SP & SP & $\mathrm{R}$ & SP & $\mathrm{R}$ & SP & \\
\hline Springbok & & & SP & & & & & $\mathrm{R}$ & SP & $\mathrm{R}$ & SP & SP & SP & $\mathrm{R}$ & $\mathrm{R}$ & & & & SP & & \\
\hline Klipspringer & & & & & & $\mathrm{R}$ & & SP & SP & & & & $\mathrm{R}$ & SP & SP & & $\mathrm{R}$ & & & & \\
\hline Oribi & & & SP & & & & & & & & SP & & & & & SP & & & & & \\
\hline Steenbok & & & SP & & & & & $\mathrm{R}$ & $\mathrm{R}$ & $\mathrm{R}$ & & SP & SP & $\mathrm{R}$ & $\mathrm{R}$ & & SP & & $\mathrm{P}$ & & \\
\hline Grysbok & & $\mathrm{R}$ & SP & $\mathrm{R}$ & $\mathrm{R}$ & SP & $\mathrm{R}$ & & & & SP & SP & & & & SP & $\mathrm{R}$ & $\mathrm{R}$ & & SP & \\
\hline Grey rhebok & & & & & & & & & & & & & & & & $\mathrm{R}$ & $\mathrm{R}$ & $\mathrm{R}$ & & & \\
\hline Cape buffalo & & SP & $\mathrm{R}$ & SP & SP & SP & SP & SP & SP & SP & $\mathrm{R}$ & $\mathrm{R}$ & $\mathrm{R}$ & SP & SP & SP & SP & & $\mathrm{R}$ & & \\
\hline Kudu & & & $\mathrm{R}$ & $\mathrm{R}$ & $\mathrm{R}$ & $\mathrm{R}$ & $\mathrm{R}$ & $\mathrm{R}$ & $\mathrm{R}$ & $\mathrm{R}$ & SP & $\mathrm{R}$ & $\mathrm{R}$ & SP & $\mathrm{R}$ & & $\mathrm{R}$ & & $\mathrm{R}$ & & \\
\hline Bushbuck & $\mathrm{R}$ & $\mathrm{R}$ & $\mathrm{R}$ & $\mathrm{R}$ & $\mathrm{R}$ & $\mathrm{R}$ & $\mathrm{R}$ & & & & SP & SP & SP & & & & & & SP & SP & \\
\hline Eland & & & SP & SP & SP & SP & SP & SP & SP & SP & SP & SP & SP & SP & SP & SP & SP & SP & SP & & \\
\hline Reedbuck & & & SP & & & & & & & & & & & & & & & & & & \\
\hline Mountain reedbuck & & & & & & & & $\mathrm{R}$ & $\mathrm{R}$ & & & & SP & & $\mathrm{R}$ & $\mathrm{R}$ & $\mathrm{R}$ & SP & & & \\
\hline
\end{tabular}




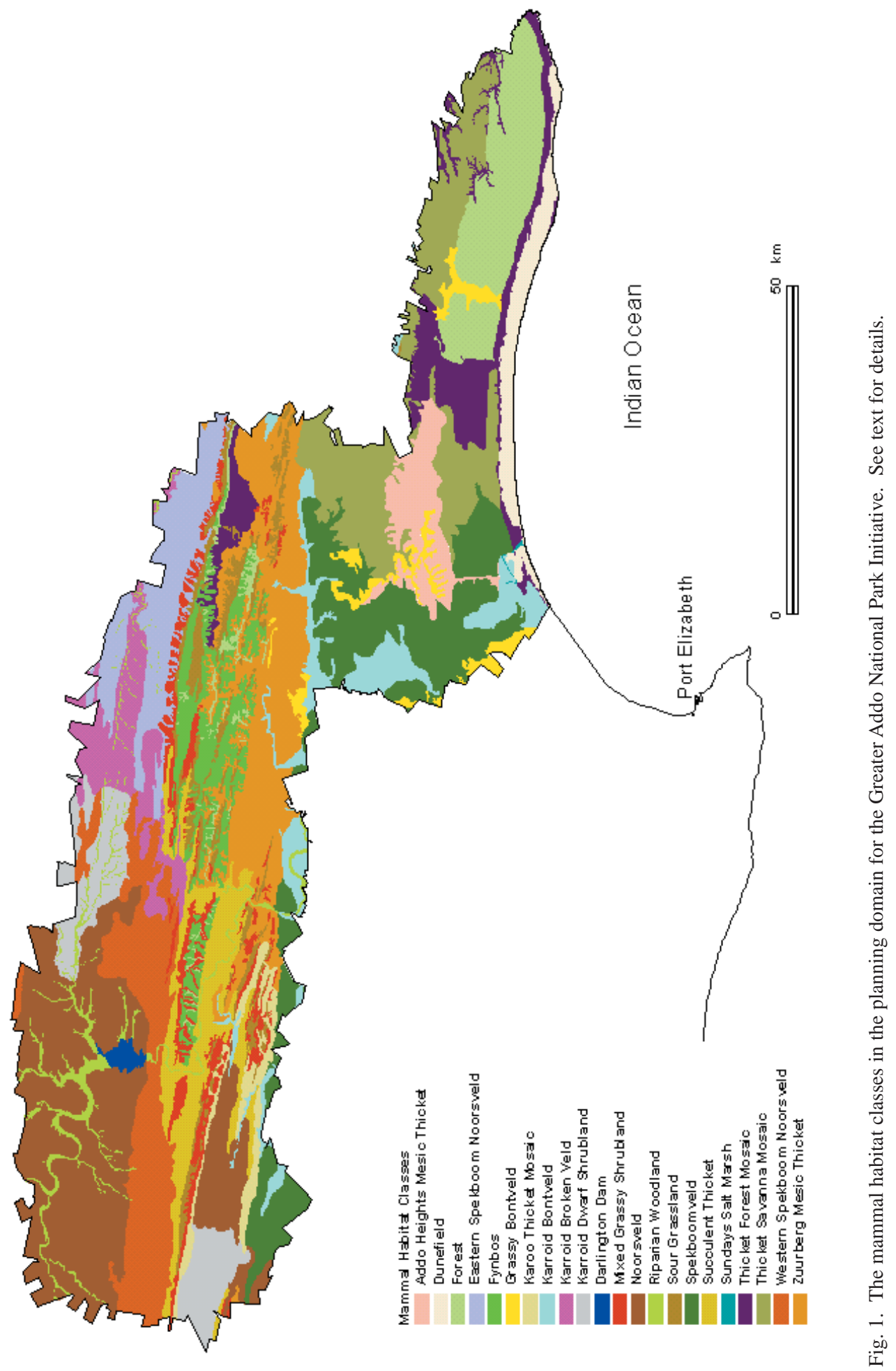


of brevity, the sources of the data used to estimate the spatial requirements have not been included in this paper.

Given that they occur along rivers or along the coastline, the density estimates for the two otter species are expressed in linear terms (individuals $/ \mathrm{km}$ ). Where the distribution of the Cape clawless otter potentially overlaps with that of the spotted-necked otter, the food resources have been equally apportioned between them, thereby reducing the potential density of each species.

A conservative approach to the estimation of the spatial requirements of the omnivores and carnivores in the GAENP planning domain was adopted because of the naturally, and relatively, low herbivore carrying capacity in some habitats, and a generally poor understanding of the ecology of the species concerned. This was achieved by: (a) usually adopting the lowest densities or largest territories or home ranges provided in the literature; (b) using the home range when territory size is not known; (c) basing, in appropriate cases, the estimates only on the sizes of the territories or home ranges of breeding adults-in these cases effective densities may be higher when non-territorial individuals (e.g., sub-adults, immatures and juveniles) are taken into account; and (d) reducing the densities in the seasonal/patchy habitats to $20 \%$ of those calculated for the "core" habitats (Boshoff et al. 2001b).

\section{Herbivores}

Given the virtual absence of information on the spatial requirements of herbivores in the GAENP planning domain, we followed a pragmatic approach in the derivation of the necessary estimates. This involves a spreadsheet model, based on forage availability estimates and the metabolic requirements of the mammal species in question. The approach followed is very similar to that described by Boshoff et al. (2001b) but some adjustments have been made to accommodate the GAENP requirements and characteristics. Although the porcupine is predominantly a herbivore, we have treated it as an omnivore and excluded it from the spreadsheet model, since it does not fit in the conventional grazer/browser classification.

The six sequential components of the model are described below:

\section{Allocation of species to foraging guilds}

Each herbivore species was classified according to one of four foraging guilds (Table 1, adapted from Collinson \& Goodman 1982), namely: bulk grazer; concentrate grazer; mixed feeder (grazer/browser); and browser.

\section{Adjustment of the agricultural stocking rate}

The recommended agricultural stocking rates (SRs) for the respective land/agricultural units, as calculated by the South African Department of Agriculture on the basis of Large Stock Units (LSUs) (Anon. 1985), were used as guidelines for estimating forage production, and ultimately the spatial requirements of herbivores within each Mammal Habitat Class. It must be emphasised that the term "spatial requirements" normally refers to an ecological response, whereas the term "stocking rates" normally refers to an operator/manager response. The definition and use of the LSU concept to determine stocking rates for livestock and wildlife is discussed in some detail by Boshoff et al. (2001b).

Where available data (cf. Stuart-Hill \& Aucamp 1993) have permitted a comparison, the agricultural stocking rate broadly agrees with published empirical data.

Agricultural management is usually aimed at maximising production (Morris et al. 1999), and therefore we adopted a highly conservative approach in the calculations for the indigenous ungulates, for the purpose of sustaining populations and protecting biodiversity. This took the form of adjusting (i.e., reducing) the Department of Agriculture stocking rate applicable to each MHC by a proportion which was estimated following a subjective assessment of the biophysical attributes, as surrogates for the productivity of forage, for the MHC in question. Key surrogates here are dominant vegetation, grass component, soil nutrient status, mean annual rainfall, rainfall seasonality, modal altitude and general topography. In this way, the agricultural SRs of MHCs characterised by low productivity, low nutrient soils and a limited grass component, were reduced by a higher percentage than those MHCs characterised by a higher productivity, relatively higher soil nutrient status and a relatively high grass component.

Thus:

$\operatorname{Adj}_{S r}=X(1+Y)$

where $A d j_{s r}=$ Adjusted stocking rate, $X=$ agricultural carrying capacity/stocking rate (ha/LSU), $Y=$ adjustment value (where, e.g., $60 \%=0.4$ ), and LSU = Large Stock Unit. 

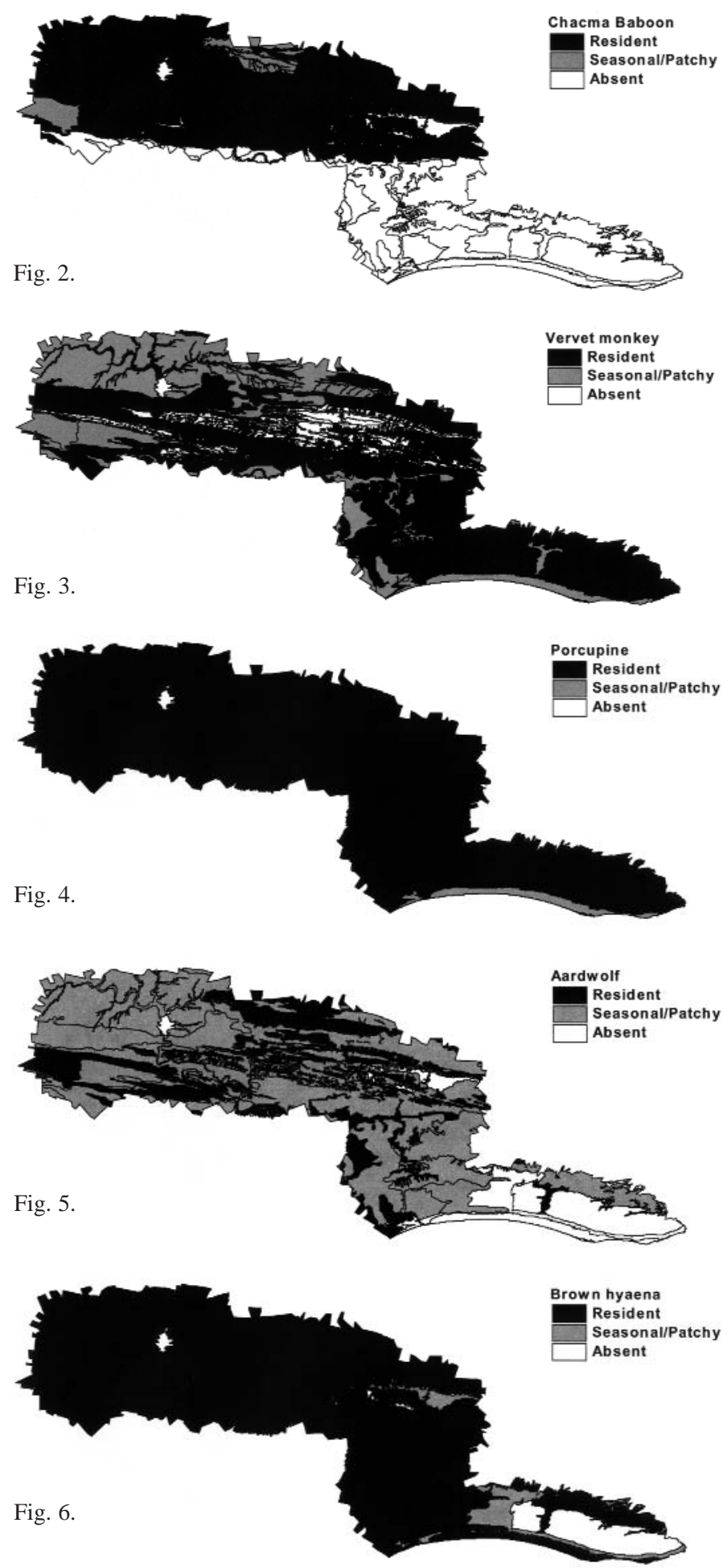

Koedoe 45/2 (2002)
Figs. 2-44. The potential distribution of the different mammals in the Greater Addo Elephant National Park planning domain, according to Mammal Habitat Class (MHC). Solid shading denotes MHCs with the potential to sustain significant resident (i.e., present all year round and breeding) populations; grey shading denotes MHCs which may be used on an ephemeral (i.e., seasonal) basis, or which may carry small populations in habitat refugia (patchy basis), and no shading denotes MHCs where the species is unlikely to occur, except perhaps for vagrants or during rare and short-lived incursions.

Department of Agriculture stocking rates were not available for some MHCs, nor could they be determined, owing to mapping scale differences. In these cases, stocking rates were estimated according to: an interpretation of the key biophysical attributes (as listed above); the stocking rates for similar MHCs; and the stocking rates for neighbouring Mammal Habitat Classes.

For the purposes of the model, these adjusted stocking rates (ha/LSU) were expressed as animal unit densities (LSU/ha).

\section{Allocation of animal units to foraging guilds, within MHCs}

The available animal units, per hectare, within each MHC (expressed as adjusted LSU/ha) were allocated to each of the four foraging guilds, where appropriate (i.e., for each guild that was represented in that MHC). To achieve this, allocations of forage (as percentages) were made for each guild within each MHC, based on subjective estimations of the proportions and nature (e.g., sweet or sour grassveld) of graze and browse, as suggested by the MHC biophysical descriptions and 
our personal knowledge of these habitats (Appendix 1). These allocations were then corroborated with the guild structures of the herbivores occurring in each Mammal Habitat Class. For example, a check was made that the distribution patterns described earlier indicated that grazers were the dominant herbivores in MHCs dominated by grass.

For pragmatic reasons, no distinction was made between the pre- and postDarlington Dam scenarios, i.e., the dam was considered to be a permanent feature. Since the dam itself (water area) it does not contribute any forage, it has been subtracted from the total area of Riparian Woodland that provides suitable hippopotamus habitat.

\section{Allocation of available animal units to individual species within foraging guilds, within MHCs}

For each MHC the available animal units, calculated in Step 3 above and expressed as adjusted LSU/ha, were allocated to the herbivore species within each foraging guild. Thus, where more than one species occurs within a single foraging guild within an MHC, the LSUs accorded to that guild are allocated to these species in equal proportions. This course was chosen owing to the paucity of information on resource partitioning within these guilds.

\section{Adjustment for seasonality/ patchiness}

Species that are resident in a MHC will most likely have different forage requirements (and possibly other ecological requirements, e.g., availability of surface water, shelter/cover) than species that are highly spatially localised or that may only be present for a limited part of a year (i.e., nomads or migrants). Therefore, there was a requirement for the model to incorporate seasonality and habitat patchiness. This was addressed by reducing by $60 \%$ the amount of forage
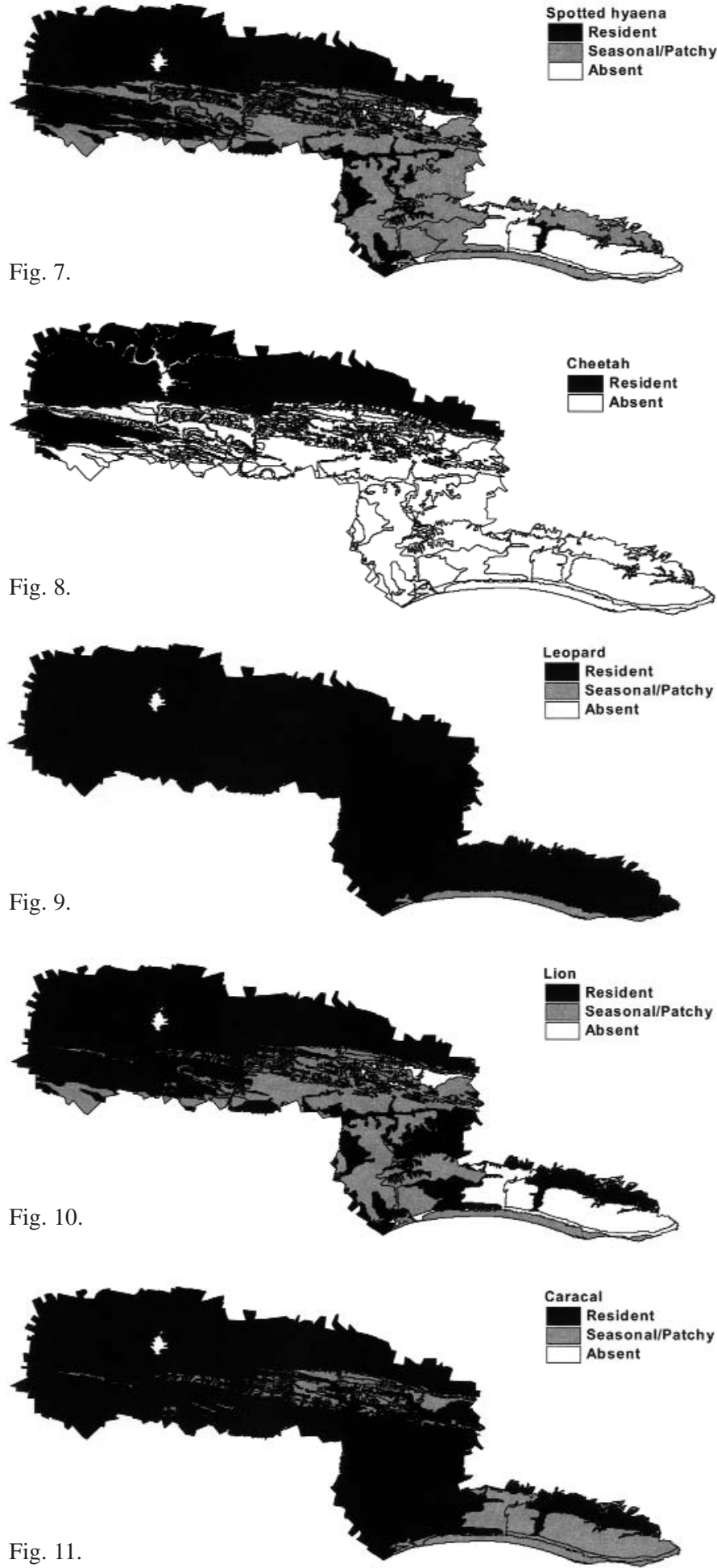

Fig. 11. 

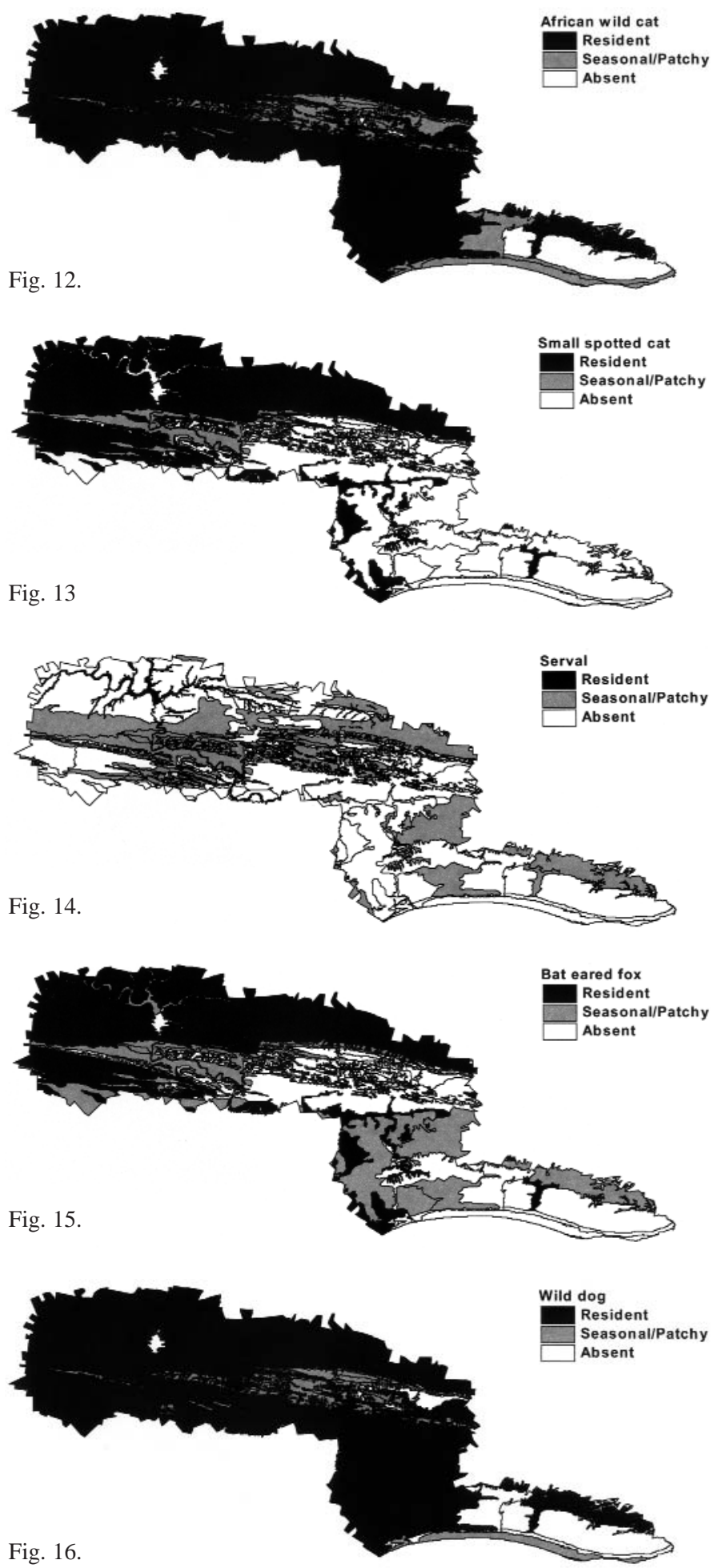

allocated (expressed as adjusted LSU/ha) to seasonal/patchy species. We assumed that the amount, and indeed quality, of resources was limiting, rather than their seasonal availability or total absence. The basis for using a value of $60 \%$ is the same as that used for a similar study in the Cape Floristic Region, where a value of $90 \%$ was used (Boshoff et al. 2001b). A value of $60 \%$ was used here to reflect the probable higher and more reliable year-round forage productivity.

Thus, each species in each MHC is classified as "resident" or "seasonal/ patchy" (see "Distributions"). The LSUs that were "released" by a "seasonal/patchy" species were reallocated, in equal proportions, to other species within the same foraging guild. This gives the recalculated number of LSUs available to each species within a Mammal Habitat Class. In cases where other species are not present in the same guild, the "released" animal equivalents (LSU/ha) were considered as "floaters" within that MHC - to be utilised across the graze/browse spectrum by the remaining species in the Mammal Habitat Class.

\section{Calculation of species specif- ic densities and spatial requirements, within each $\mathrm{MHC}$}

The number of individuals of a species per ha (density), within each MHC, was calculated as follows:

$D=L S U_{\text {rec }} / S_{\text {equ }}$

where $D$ = density (number of individuals/ ha), $L S U_{\text {rec }}=$ recalculated LSUs per species (as calculated in steps 1-5 above) and $S_{\text {equ }}=$ species' LSU equivalent.

The LSU equivalents for the species follow Grossman (1991); that for African elephant follows Meissner (1982).

The estimated spatial requirement for an individual of each species, within each MHC, is calculated as follows: 
$S p R q_{i}=1 / D$

where $S p R q_{i}=$ spatial requirement (ha/individual) of an individual, $D=$ density (individuals/ha - from equation 2).

\section{Constraints}

A limitation on the spatial requirements of some herbivores is provided by social interaction, namely intolerance of conspecifics, as well as a number of other constraints, e.g., presence of surface water, seasonal food availability. It is known that, irrespective of the availability of forage, social and other constraints can limit the densities of ungulates (e.g., see Moen 1973), and for some species the availability of food, water and shelter is superseded by social factors in determining densities. In this regard, the spatial requirements predicted by our model were compared, where possible, with available information to investigate whether species' social constraints had been violated.

\section{Model testing}

The outputs of the model were tested by comparing spatial requirement estimates derived from the model with published, empirically derived observations of densities of species for which appropriate data are available. Such data are not available for complete species assemblages.

\section{Hippopotamus}

For those parts of MHCs where hippopotamus can potentially occur, a separate spreadsheet model was constructed. It differs from the model for the MHCs without hippopotamus in that hippopotamus has been inserted as an additional herbivore (it is a bulk grazer). This results in adjustments to the allocation of forage between bulk grazers within these parts of MHCs, and ultimately the densities of all species within this foraging guild.

There is no published information on the densities and spatial requirements of hippopotamus in the GAENP domain, or even in the Eastern Cape,
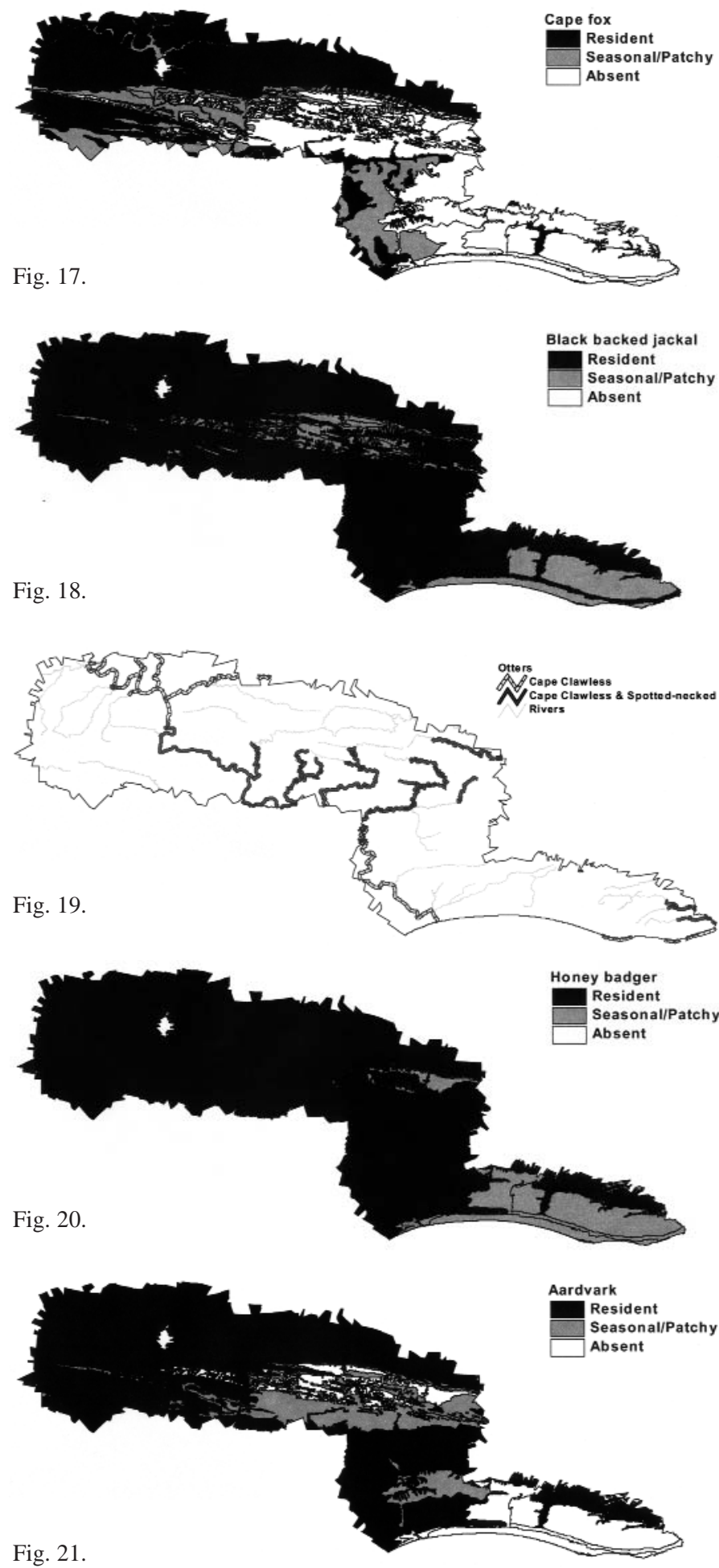

Fig. 21. 

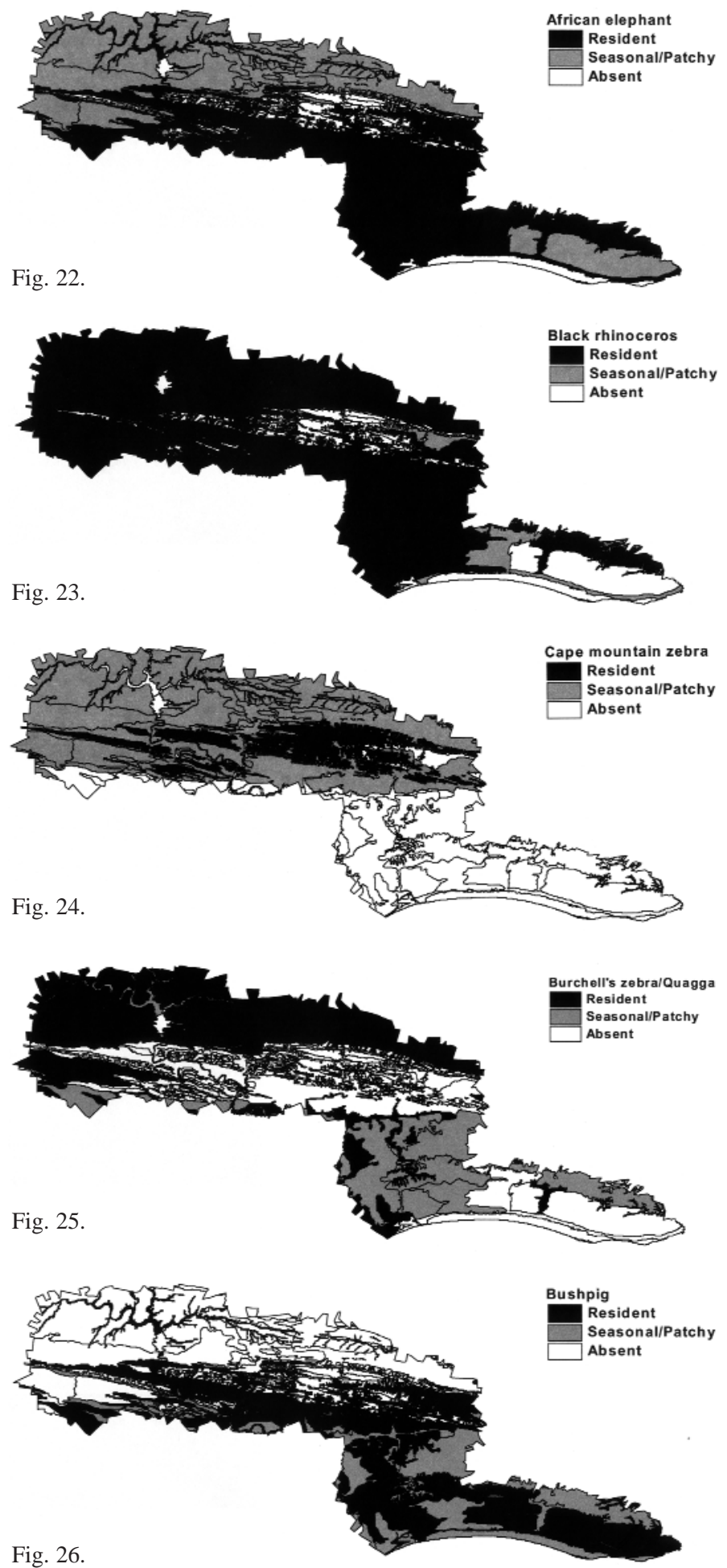

to validate the estimates provided by the model.

\section{Results}

Omnivores and carnivores

The estimates of the spatial requirements/densities for the omnivores and carnivores are provided in Table 3. As an example of the basis for the estimation of the spatial requirements, the case of the chacma baboon is given (Box 1; cf. Table 3). The

Box 1: Estimation of the spatial requirements of the chacma baboon.

\section{Breeding unit/social structure}

Baboons are highly social, living in female bonded troops of between four and around 100130 individuals, with one adult male in small troops and up to 12 males in large troops; average troop size is 40 (Skinner \& Smithers 1990, Apps 1996) and troop size is apparently correlated with habitat quality.

Breeding density/home range/ territory size

Troops have home ranges but they are not territorial and rather tend to avoid other troops (Apps 1996). In the Good Hope section of the Cape Peninsula National Park home ranges of three troops of 20, 35 and 80 baboons were $9.1,14.8$ and $33.7 \mathrm{~km}^{2}$, respectively, with home range being related to size of troop (Devore \& Hall 1965). Home ranges of 4004000 ha have been recorded. 


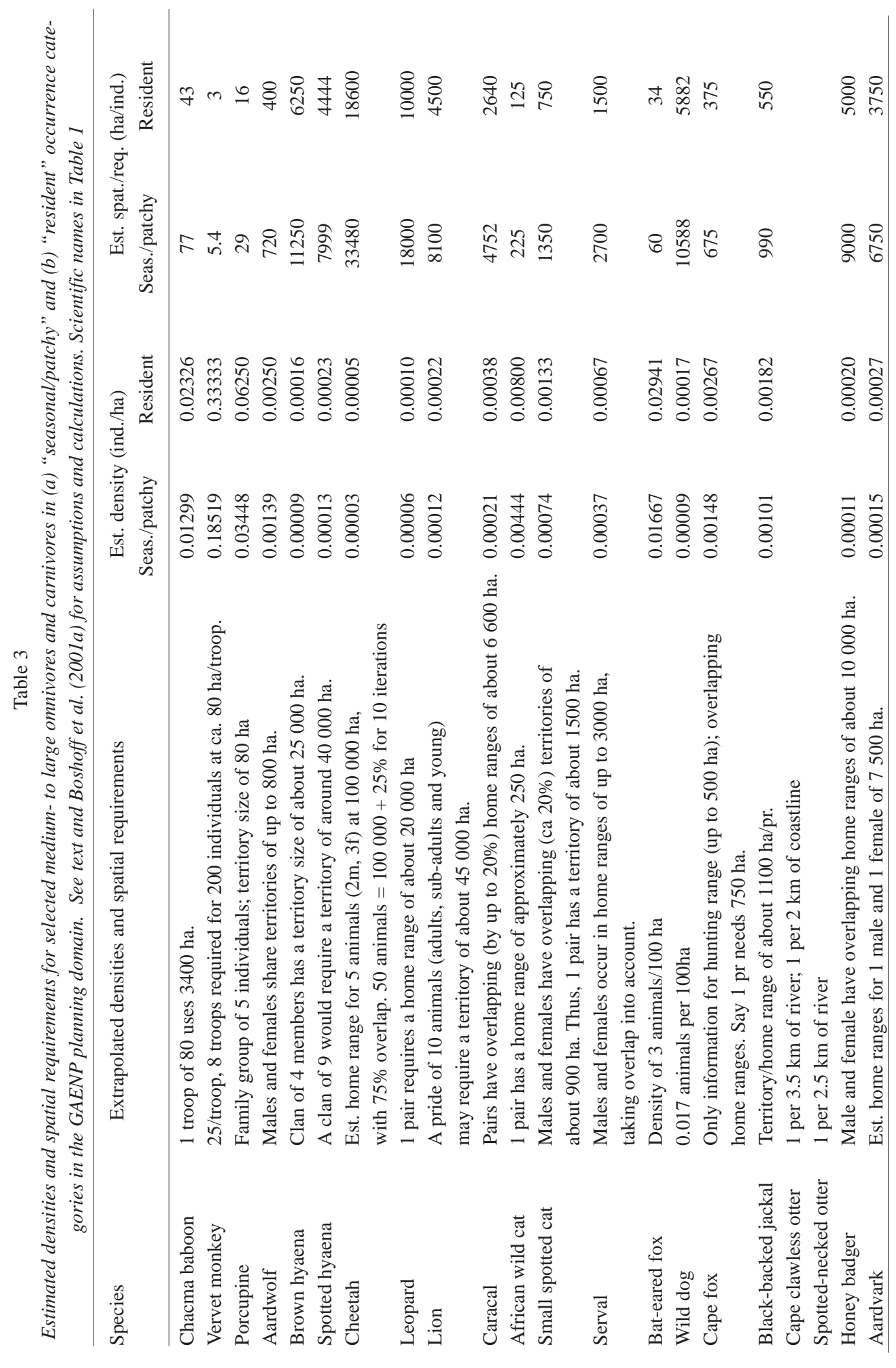


Table 4

Estimated densities and spatial requirements of the larger mammalian herbivores in areas of $20 \mathrm{Mam}$ malian Habitat Classes in the GAENP planning domain that do not contain hippopotamus habitat. Data derived from a spreadsheet model. See text for calculations and assumptions. Scientific names in Table 1

\begin{tabular}{|c|c|c|c|c|c|c|}
\hline $\begin{array}{l}\text { Mammal } \\
\text { Habitat } \\
\text { Class }\end{array}$ & Species & $\begin{array}{l}\text { Density } \\
\text { (ind./ha) }\end{array}$ & $\begin{array}{c}\text { Est. spat. } \\
\text { req. } \\
\text { (ha/ind.) }\end{array}$ & Species & $\begin{array}{l}\text { Density } \\
\text { (ind./ha) }\end{array}$ & $\begin{array}{c}\text { Est. spat. } \\
\text { req. } \\
\text { (ha/ind.) }\end{array}$ \\
\hline \multirow[t]{3}{*}{ Forest } & African elephant & 0.00035 & 2876 & Common duiker & 0.01704 & 59 \\
\hline & Bushpig & 0.01758 & 57 & Bushbuck & 0.03833 & 26 \\
\hline & Blue duiker & 0.16611 & 6 & & & \\
\hline \multirow{4}{*}{$\begin{array}{l}\text { Thicket Forest } \\
\text { Mosaic }\end{array}$} & African elephant & 0.00540 & 185 & Common duiker & 0.06617 & 15 \\
\hline & Black rhinoceros & 0.00361 & 277 & Grysbok & 0.34740 & 3 \\
\hline & Bushpig & 0.06818 & 15 & Cape buffalo & 0.00208 & 482 \\
\hline & Blue duiker & 0.69481 & 1 & Bushbuck & 0.16034 & 6 \\
\hline \multirow{9}{*}{$\begin{array}{l}\text { Thicket Savanna } \\
\text { Mosaic }\end{array}$} & African elephant & 0.00540 & 185 & Oribi & 0.04082 & 25 \\
\hline & Black rhinoceros & 0.00807 & 124 & Steenbok & 0.06122 & 16 \\
\hline & Burchell’s zebra & 0.00866 & 116 & Grysbok & 0.06122 & 16 \\
\hline & Bushpig & 0.00974 & 103 & Cape buffalo & 0.02136 & 47 \\
\hline & Warthog & 0.01143 & 88 & Kudu & 0.02466 & 41 \\
\hline & Red hartebeest & 0.00772 & 130 & Bushbuck & 0.10243 & 10 \\
\hline & Blue duiker & 0.12245 & 8 & Eland & 0.00198 & 504 \\
\hline & Common duiker & 0.14796 & 7 & Reedbuck & 0.01143 & 88 \\
\hline & Springbok & 0.01429 & 70 & & & \\
\hline \multirow{6}{*}{$\begin{array}{l}\text { Zuurberg Mesic } \\
\text { Thicket }\end{array}$} & African elephant & 0.00229 & 436 & Grysbok & 0.10621 & 9 \\
\hline & Black rhinoceros & 0.00386 & 259 & Cape buffalo & 0.00099 & 1011 \\
\hline & Cape mtn. zebra & 0.00168 & 595 & Kudu & 0.01180 & 85 \\
\hline & Bushpig & 0.02897 & 35 & Bushbuck & 0.04902 & 20 \\
\hline & Blue duiker & 0.21242 & 5 & Eland & 0.00182 & 551 \\
\hline & Common duiker & 0.07081 & 14 & & & \\
\hline \multirow{6}{*}{$\begin{array}{l}\text { Addo Heights } \\
\text { Mesic Thicket }\end{array}$} & African elephant & 0.00229 & 436 & Common duiker & 0.07081 & 14 \\
\hline & Black rhinoceros & 0.00386 & 259 & Grysbok & 0.10621 & 9 \\
\hline & Burchell’s zebra & 0.00160 & 623 & Cape buffalo & 0.00099 & 1011 \\
\hline & Bushpig & 0.02897 & 35 & Kudu & 0.01180 & 85 \\
\hline & Warthog & 0.00094 & 1063 & Bushbuck & 0.04902 & 20 \\
\hline & Blue duiker & 0.21242 & 5 & Eland & 0.00182 & 551 \\
\hline \multirow{7}{*}{$\begin{array}{l}\text { Succulent } \\
\text { Thicket }\end{array}$} & African elephant & 0.00111 & 898 & Common duiker & 0.06092 & 16 \\
\hline & Black rhinoceros & 0.00332 & 301 & Klipspringer & 0.07833 & 13 \\
\hline & Cape mtn. zebra & 0.00076 & 1323 & Grysbok & 0.02948 & 34 \\
\hline & Bushpig & 0.01407 & 71 & Cape buffalo & 0.00045 & 2247 \\
\hline & Warthog & 0.00571 & 175 & Kudu & 0.01015 & 98 \\
\hline & Red hartebeest & 0.00386 & 259 & Bushbuck & 0.04218 & 24 \\
\hline & Blue duiker & 0.05896 & 17 & Eland & 0.00088 & 1134 \\
\hline \multirow[t]{6}{*}{ Spekboomveld } & African elephant & 0.00142 & 706 & Common duiker & 0.06128 & 16 \\
\hline & Black rhinoceros & 0.00334 & 299 & Grysbok & 0.09192 & 11 \\
\hline & Burchell’s zebra & 0.00069 & 1452 & Cape buffalo & 0.00042 & 2354 \\
\hline & Bushpig & 0.01791 & 56 & Kudu & 0.01021 & 98 \\
\hline & Warthog & 0.00727 & 138 & Bushbuck & 0.04242 & 24 \\
\hline & Blue duiker & 0.06566 & 15 & Eland & 0.00112 & 891 \\
\hline Eastern & African elephant & 0.00027 & 3753 & Springbok & 0.02716 & 37 \\
\hline Spekboom & Black rhinoceros & 0.00387 & 258 & Klipspringer & 0.03175 & 32 \\
\hline Noorsveld & Cape mtn. zebra & 0.00353 & 284 & Steenbok & 0.10648 & 9 \\
\hline
\end{tabular}


Table 4 (continued)

\begin{tabular}{|c|c|c|c|c|c|c|}
\hline $\begin{array}{l}\text { Mammal } \\
\text { Habitat } \\
\text { Class }\end{array}$ & Species & $\begin{array}{l}\text { Density } \\
\text { (ind./ha) }\end{array}$ & $\begin{array}{c}\text { Est. spat. } \\
\text { req. } \\
\text { (ha/ind.) }\end{array}$ & Species & $\begin{array}{l}\text { Density } \\
\text { (ind./ha) }\end{array}$ & $\begin{array}{c}\text { Est. spat. } \\
\text { req. } \\
\text { (ha/ind.) }\end{array}$ \\
\hline & Burchell's zebra & 0.01852 & 54 & Cape buffalo & 0.00208 & 482 \\
\hline & Warthog & 0.00667 & 150 & Kudu & 0.01183 & 85 \\
\hline & Black wildebeest & 0.00121 & 828 & Eland & 0.00069 & 1458 \\
\hline & Red hartebeest & 0.00450 & 222 & Mtn. reedbuck & 0.01282 & 78 \\
\hline & Common duiker & 0.07099 & 14 & & & \\
\hline Western & African elephant & 0.0002 & 24587 & Springbok & 0.00404 & 248 \\
\hline Spekboom & Black rhinoceros & 0.00348 & 287 & Klipspringer & 0.02857 & 35 \\
\hline \multirow[t]{5}{*}{ Noorsveld } & Cape mtn. zebra & 0.00241 & 416 & Steenbok & 0.09583 & 10 \\
\hline & Burchell's zebra & 0.01263 & 79 & Cape buffalo & 0.00142 & 706 \\
\hline & Warthog & 0.00606 & 165 & Kudu & 0.01065 & 94 \\
\hline & Red hartebeest & 0.00410 & 244 & Eland & 0.00056 & 1782 \\
\hline & Common duiker & 0.06389 & 16 & Mtn. reedbuck & 0.01166 & 86 \\
\hline \multirow[t]{6}{*}{ Noorsveld } & African elephant & 0.00020 & 5004 & Common duiker & 0.06366 & 16 \\
\hline & Black rhinoceros & 0.00347 & 288 & Springbok & 0.02037 & 49 \\
\hline & Cape mtn. zebra & 0.00220 & 454 & Steenbok & 0.09549 & 10 \\
\hline & Burchell's zebra & 0.01157 & 86 & Cape buffalo & 0.00130 & 770 \\
\hline & Warthog & 0.00833 & 120 & Kudu & 0.01061 & 94 \\
\hline & Red hartebeest & 0.00563 & 178 & Eland & 0.00051 & 1944 \\
\hline \multirow[t]{7}{*}{ Grassy Bontveld } & African elephant & 0.00252 & 397 & Springbok & 0.00667 & 150 \\
\hline & Black rhinoceros & 0.00801 & 125 & Oribi & 0.01905 & 53 \\
\hline & Burchell's zebra & 0.01221 & 82 & Grysbok & 0.02593 & 39 \\
\hline & Bushpig & 0.00455 & 220 & Cape buffalo & 0.00753 & 133 \\
\hline & Warthog & 0.01733 & 58 & Kudu & 0.00288 & 347 \\
\hline & Red hartebeest & 0.01171 & 85 & Bushbuck & 0.01197 & 84 \\
\hline & Common duiker & 0.01728 & 58 & Eland & 0.00093 & 1080 \\
\hline \multirow[t]{7}{*}{ Karroid Bontveld } & African elephant & 0.00210 & 477 & Springbok & 0.00556 & 180 \\
\hline & Black rhinoceros & 0.00617 & 162 & Steenbok & 0.03086 & 32 \\
\hline & Burchell’s zebra & 0.00842 & 119 & Grysbok & 0.03086 & 32 \\
\hline & Bushpig & 0.00379 & 264 & Cape buffalo & 0.00519 & 193 \\
\hline & Warthog & 0.01667 & 60 & Kudu & 0.01886 & 53 \\
\hline & Red hartebeest & 0.01126 & 89 & Bushbuck & 0.01425 & 70 \\
\hline & Common duiker & 0.02058 & 49 & Eland & 0.00077 & 1296 \\
\hline \multirow{8}{*}{$\begin{array}{l}\text { Karoo Thicket } \\
\text { Mosaic }\end{array}$} & African elephant & 0.00157 & 635 & Klipspringer & 0.07093 & 14 \\
\hline & Black rhinoceros & 0.00301 & 332 & Steenbok & 0.02546 & 39 \\
\hline & Cape mtn. zebra & 0.00198 & 504 & Cape buffalo & 0.00467 & 214 \\
\hline & Bushpig & 0.00284 & 352 & Kudu & 0.00919 & 109 \\
\hline & Warthog & 0.00333 & 300 & Bushbuck & 0.01175 & 85 \\
\hline & Red hartebeest & 0.00225 & 444 & Eland & 0.00058 & 1728 \\
\hline & Common duiker & 0.05517 & 18 & Mtn. reedbuck & 0.00641 & 156 \\
\hline & Springbok & 0.00417 & 240 & & & \\
\hline \multirow{7}{*}{$\begin{array}{l}\text { Karroid Dwarf } \\
\text { Shrubland }\end{array}$} & African elephant & 0.00030 & 3336 & Springbok & 0.03055 & 33 \\
\hline & Black rhinoceros & 0.00480 & 208 & Klipspringer & 0.02381 & 42 \\
\hline & Cape mtn. zebra & 0.00176 & 567 & Steenbok & 0.13194 & 8 \\
\hline & Burchell's zebra & 0.00926 & 108 & Cape buffalo & 0.00104 & 963 \\
\hline & Warthog & 0.01250 & 80 & Kudu & 0.00309 & 324 \\
\hline & Red hartebeest & 0.00845 & 118 & Eland & 0.00077 & 1296 \\
\hline & Common duiker & 0.01852 & 54 & & & \\
\hline
\end{tabular}


Table 4 (continued)

\begin{tabular}{|c|c|c|c|c|c|c|}
\hline $\begin{array}{l}\text { Mammal } \\
\text { Habitat } \\
\text { Class }\end{array}$ & Species & $\begin{array}{l}\text { Density } \\
\text { (ind./ha) }\end{array}$ & $\begin{array}{c}\text { Est. spat. } \\
\text { req. } \\
\text { (ha/ind.) }\end{array}$ & Species & $\begin{array}{l}\text { Density } \\
\text { (ind./ha) }\end{array}$ & $\begin{array}{c}\text { Est. spat. } \\
\text { req. } \\
\text { (ha/ind.) }\end{array}$ \\
\hline Karroid Broken & African elephant & 0.00034 & 2919 & Springbok & 0.03492 & 29 \\
\hline \multirow[t]{7}{*}{ Veld } & Black rhinoceros & 0.00364 & 275 & Klipspringer & 0.02449 & 41 \\
\hline & Cape mtn. zebra & 0.00252 & 397 & Steenbok & 0.10000 & 10 \\
\hline & Burchell’s zebra & 0.01323 & 76 & Cape buffalo & 0.00148 & 674 \\
\hline & Warthog & 0.00857 & 117 & Kudu & 0.01111 & 90 \\
\hline & Black wildebeest & 0.00155 & 644 & Eland & 0.00088 & 1134 \\
\hline & Red hartebeest & 0.00579 & 173 & Mtn. reedbuck & 0.01648 & 61 \\
\hline & Common duiker & 0.01905 & 53 & & & \\
\hline \multirow[t]{5}{*}{ Sour Grassland } & Cape mtn. zebra & 0.01905 & 53 & Grey rhebok & 0.06000 & 17 \\
\hline & Red hartebeest & 0.00405 & 247 & Cape buffalo & 0.00280 & 357 \\
\hline & Common duiker & 0.02222 & 45 & Eland & 0.00370 & 270 \\
\hline & Oribi & 0.02143 & 47 & Mtn. reedbuck & 0.04615 & 22 \\
\hline & Grysbok & 0.03333 & 30 & & & \\
\hline Mixed Grassy & African elephant & 0.00085 & 1182 & Grysbok & 0.07320 & 14 \\
\hline \multirow[t]{6}{*}{ Shrubland } & Black rhinoceros & 0.00266 & 376 & Grey rhebok & 0.03922 & 26 \\
\hline & Cape mtn. zebra & 0.01494 & 67 & Cape buffalo & 0.00220 & 455 \\
\hline & Red hartebeest & 0.01060 & 94 & Kudu & 0.00813 & 123 \\
\hline & Common duiker & 0.04880 & 20 & Eland & 0.00218 & 459 \\
\hline & Klipspringer & 0.06274 & 16 & Mtn. reedbuck & 0.03017 & 33 \\
\hline & Steenbok & 0.02614 & 38 & & & \\
\hline \multirow[t]{4}{*}{ Fynbos } & Cape mtn. zebra & 0.00756 & 132 & Grey rhebok & 0.03492 & 29 \\
\hline & Red hartebeest & 0.00172 & 583 & Eland & 0.00353 & 284 \\
\hline & Common duiker & 0.06349 & 16 & Mtn. reedbuck & 0.00488 & 205 \\
\hline & Grysbok & 0.38094 & 3 & & & \\
\hline Riparian & African elephant & 0.00308 & 324 & Common duiker & 0.16931 & 6 \\
\hline \multirow[t]{6}{*}{ Woodland } & Black rhinoceros & 0.00924 & 108 & Springbok & 0.01429 & 70 \\
\hline & Burchell's zebra & 0.01299 & 77 & Steenbok & 0.06349 & 16 \\
\hline & Bushpig & 0.03896 & 26 & Cape buffalo & 0.03204 & 31 \\
\hline & Warthog & 0.06857 & 15 & Kudu & 0.02822 & 35 \\
\hline & Red hartebeest & 0.01158 & 86 & Bushbuck & 0.02930 & 34 \\
\hline & Blue duiker & 0.12698 & 8 & Eland & 0.00198 & 504 \\
\hline \multirow[t]{2}{*}{ Dunefield } & Bushpig & 0.00135 & 743 & Grysbok & 0.00658 & 152 \\
\hline & Common duiker & 0.00439 & 228 & Bushbuck & 0.00304 & 329 \\
\hline
\end{tabular}

estimated requirement of 3400 ha for a troop of 80 individuals is derived from this information.

\section{Herbivores}

The model's estimations of the spatial requirements (and densities) for all species, except hippopotamus, in a single MHC are listed in Table 4. The estimations for MHCs that can potentially carry hippopotamus are listed in Table 5 . The inclusion of hippopota- mus within certain MHCs has, predictably, had the effect of lowering the densities and increasing the spatial requirements of all the bulk grazers in these habitats.

Thicket forest mosaic and thicket savanna mosaic can potentially carry the highest densities of elephant ( 0.54 individuals $\left./ \mathrm{km}^{2}\right)$. Riparian woodland and thicket savanna mosaic can potentially carry the highest densities (0.8-0.9 individuals $\left./ \mathrm{km}^{2}\right)$ of black rhinoceros, as they can Cape buffalo 
(2.1-3.2 individuals $/ \mathrm{km}^{2}$ ) and common duiker (14.7-16.9 individuals $/ \mathrm{km}^{2}$ ).

In the case of the African elephant, a megaherbivore, social constraints (e.g., inter-bull aggression-Kerley \& Boshoff 1997; Whitehouse \& Kerley 2002) have not been violated by the model's predictions. Interaction between individuals of another megaherbivore, the black rhinoceros, provides a major constraint (Adcock 1994) and a general minimum spatial (social) requirement of $200 \mathrm{ha} /$ animal has been suggested (see Hall-Martin \& Knight 1994). Only four of the 16 density estimates provided by the model are above this suggested maximum density for this species; given the nature of the habitats in question, these estimates require field testing. It is noteworthy that in xeric succulent thicket in the Andries Vosloo Kudu Reserve, a density of as high as 1 male rhino/50 ha has been recorded (Adcock 1994).

It is difficult to obtain empirical data to test the estimates provided by the spreadsheet models. There is virtually no information for the study area, and where information is available, it is normally unsuitable due to a number of constraints. For example, populations of the larger mammal species in the current AENP (including the Zuurberg portion), and indeed in other national parks and nature reserves in the region, are not natural and are influenced by factors such as presence of fencing (affecting population numbers, and limiting natural movements), and the absence of the large predators (influencing population structure and causing behavioural aberrations). Thus, densities may be relatively high in protected areas due to a combination of pristine, or near-pristine, habitats and absence of the larger predators. In addition, the spatial requirements of the herbivores are known to vary between habitats, owing to spatial variation in forage quality and availability, and shelter. Thus, until empirical studies have been conducted in the MHCs in the GAENP planning domain, testing of the model's predictions is always going to be problematic.
Notwithstanding the contraints mentioned above, an attempt was made to compare empirically obtained spatial requirement data with the predictions from the model (Table 6). With few exceptions, the data derived from the model were broadly corroborated for those herbivore species for which published information is available, thereby indicating that realistic values were generated by the model. It is again emphasised that the predictions from the model should be regarded as hypotheses and should be tested through field studies and modified where necessary (see also General Discussion).

\section{Discussion}

The spatial requirement and density data generated by the model described here are considered to be realistic. They can therefore be meaningfully used in the conservation planning exercise for the larger mammals in the GAENP planning domain. These data also provide useful information for guiding conservation management decisions, for example, determining multi-species assemblages and preliminary stocking rates of herbivores in the proposed GAENP.

It is emphasised that the estimated densities or spatial requirements refer to a situation where the entire suite of potentially occurring species is available and present, and the habitats in which they can occur are in an "intact" or "potentially restorable" state. Any deviation from this scenario, e.g., due to the unavailability of a species (for various reasons) or total habitat transformation, will require manipulation of the data and rerunning of the model.

We recognise, however, that the model greatly oversimplifies the highly complex intraspecific and inter-specific mammal interactions, and the equally complex animal-plant relationships, the latter often being influenced by seasonality. There are, however, no alternatives when working at this scale, and with so little ecological information available for the species concerned. 
Table 5

Estimated densities and spatial requirements values of the larger mammalian herbivores in areas of nine

Mammalian Habitat Classes in the GAENP planning domain that contain hippopotamus habitat. Data derived from a spreadsheet model. See text for calculations and assumptions. Scientific names in Table 1

\begin{tabular}{|c|c|c|c|c|c|c|}
\hline $\begin{array}{l}\text { Mammal } \\
\text { Habitat } \\
\text { Class }\end{array}$ & Species & $\begin{array}{l}\text { Density } \\
\text { (ind./ha) }\end{array}$ & $\begin{array}{c}\text { Est. spat. } \\
\text { req. } \\
\text { (ha/ind.) }\end{array}$ & Species & $\begin{array}{l}\text { Density } \\
\text { (ind./ha) }\end{array}$ & $\begin{array}{c}\text { Est. spat. } \\
\text { req. } \\
\text { (ha/ind.) }\end{array}$ \\
\hline Thicket Forest & African elephant & 0.00540 & 185 & Common duiker & 0.06617 & 15 \\
\hline \multirow[t]{4}{*}{ Mosaic } & Black rhinoceros & 0.00361 & 277 & Grysbok & 0.34740 & 3 \\
\hline & Bushpig & 0.06818 & 15 & Cape buffalo & 0.00104 & 963 \\
\hline & Hippopotamus & 0.00198 & 504 & Bushbuck & 0.16034 & 6 \\
\hline & Blue duiker & 0.69481 & 1 & & & \\
\hline Thicket & African elephant & 0.005395 & 185 & Springbok & 0.014286 & 70 \\
\hline Savanna & Black rhinoceros & 0.00807 & 124 & Oribi & 0.040816 & 25 \\
\hline \multirow[t]{7}{*}{ Mosaic } & Burchell's zebra & 0.005772 & 173 & Steenbok & 0.061224 & 16 \\
\hline & Bushpig & 0.00974 & 103 & Grysbok & 0.061224 & 16 \\
\hline & Warthog & 0.011429 & 88 & Cape buffalo & 0.011571 & 86 \\
\hline & Hippopotamus & 0.005527 & 181 & Kudu & 0.02466 & 41 \\
\hline & Red hartebeest & 0.007722 & 130 & Bushbuck & 0.102432 & 10 \\
\hline & Blue duiker & 0.122449 & 8 & Eland & 0.001984 & 504 \\
\hline & Common duiker & 0.147958 & 7 & Reedbuck & 0.011429 & 88 \\
\hline Zuurberg Mesic & African elephant & 0.00229 & 436 & Common duiker & 0.07081 & 14 \\
\hline \multirow{5}{*}{ Thicket } & Black rhinoceros & 0.00386 & 259 & Grysbok & 0.10621 & 9 \\
\hline & Cape mtn. zebra & 0.00112 & 893 & Cape buffalo & 0.00066 & 1516 \\
\hline & Bushpig & 0.02897 & 35 & Kudu & 0.01180 & 85 \\
\hline & Hippopotamus & 0.00173 & 577 & Bushbuck & 0.04902 & 20 \\
\hline & Blue duiker & 0.21242 & 5 & Eland & 0.00182 & 551 \\
\hline Succulent & African elephant & 0.00111 & 898 & Common duiker & 0.06092 & 16 \\
\hline \multirow[t]{7}{*}{ Thicket } & Black rhinoceros & 0.00332 & 301 & Klipspringer & 0.07833 & 13 \\
\hline & Cape mtn. zebra & 0.00050 & 1985 & Grysbok & 0.02948 & 34 \\
\hline & Bushpig & 0.01407 & 71 & Cape buffalo & 0.00030 & 3371 \\
\hline & Warthog & 0.00571 & 175 & Kudu & 0.01015 & 98 \\
\hline & Hippopotamus & 0.00078 & 1283 & Bushbuck & 0.04218 & 24 \\
\hline & Red hartebeest & 0.00386 & 259 & Eland & 0.00088 & 1134 \\
\hline & Blue duiker & 0.05896 & 17 & & & \\
\hline \multirow[t]{7}{*}{ Spekboomveld } & African elephant & 0.00142 & 706 & Common duiker & 0.06128 & 16 \\
\hline & Black rhinoceros & 0.00334 & 299 & Grysbok & 0.09192 & 11 \\
\hline & Burchell's zebra & 0.00046 & 2178 & Cape buffalo & 0.00028 & 3531 \\
\hline & Bushpig & 0.01791 & 56 & Kudu & 0.01021 & 98 \\
\hline & Warthog & 0.00727 & 138 & Bushbuck & 0.04242 & 24 \\
\hline & Hippopotamus & 0.00074 & 1344 & Eland & 0.00112 & 891 \\
\hline & Blue duiker & 0.06566 & 15 & & & \\
\hline Western & African elephant & 0.00022 & 4587 & Springbok & 0.00404 & 248 \\
\hline Spekboom & Black rhinoceros & 0.00348 & 287 & Klipspringer & 0.02857 & 35 \\
\hline \multirow[t]{6}{*}{ Noorsveld } & Cape mtn. zebra & 0.00180 & 554 & Steenbok & 0.09583 & 10 \\
\hline & Burchell's zebra & 0.00689 & 145 & Cape buffalo & 0.00106 & 942 \\
\hline & Warthog & 0.00606 & 165 & Kudu & 0.01065 & 94 \\
\hline & Hippopotamus & 0.00203 & 493 & Eland & 0.00056 & 1782 \\
\hline & Red hartebeest & 0.00410 & 244 & Mtn. reedbuck & 0.01166 & 86 \\
\hline & Common duiker & 0.06389 & 16 & & & \\
\hline \multirow[t]{2}{*}{ Noorsveld } & African elephant & 0.00020 & 5004 & Common duiker & 0.06366 & 16 \\
\hline & Black rhinoceros & 0.00347 & 288 & Springbok & 0.02037 & 49 \\
\hline
\end{tabular}


Table 5 (continued)

\begin{tabular}{llcclcc}
\hline $\begin{array}{l}\text { Mammal } \\
\text { Habitat } \\
\text { Class }\end{array}$ & Species & $\begin{array}{c}\text { Density } \\
\text { (ind./ha) }\end{array}$ & $\begin{array}{c}\text { Est. spat. } \\
\text { req. } \\
\text { (ha/ind.) }\end{array}$ & Species & $\begin{array}{c}\text { Density } \\
\text { (ind./ha) }\end{array}$ & $\begin{array}{c}\text { Est. spat. } \\
\text { req. } \\
\text { (ha/ind.) }\end{array}$ \\
\hline \multirow{5}{*}{ Karroid } & Cape mtn. zebra & 0.00165 & 605 & Steenbok & 0.09549 & 10 \\
& Burchell's zebra & 0.00631 & 158 & Cape buffalo & 0.00097 & 1027 \\
& Warthog & 0.00833 & 120 & Kudu & 0.01061 & 94 \\
& Hippopotamus & 0.00186 & 538 & Eland & 0.00051 & 1944 \\
& Red hartebeest & 0.00563 & 178 & & & \\
& African elephant & 0.00210 & 477 & Springbok & 0.00556 & 180 \\
& Black rhinoceros & 0.00617 & 162 & Steenbok & 0.03086 & 32 \\
& Burchell's zebra & 0.00561 & 178 & Grysbok & 0.03086 & 32 \\
& Bushpig & 0.00379 & 264 & Cape buffalo & 0.00346 & 289 \\
& Warthog & 0.01667 & 60 & Kudu & 0.01886 & 53 \\
Riparian & Hippopotamus & 0.00165 & 605 & Bushbuck & 0.01425 & 70 \\
Woodland & Red hartebeest & 0.01126 & 89 & Eland & 0.00077 & 1296 \\
& Common duiker & 0.02058 & 49 & & & \\
& African elephant & 0.00308 & 324 & Common duiker & 0.16931 & 6 \\
& Black rhinoceros & 0.00924 & 108 & Springbok & 0.01429 & 70 \\
& Burchell's zebra & 0.00866 & 116 & Steenbok & 0.06349 & 16 \\
& Bushpig & 0.03896 & 26 & Cape buffalo & 0.01736 & 58 \\
& Warthog & 0.06857 & 15 & Kudu & 0.02822 & 35 \\
& Hippopotamus & 0.00829 & 121 & Bushbuck & 0.02930 & 34 \\
& Red hartebeest & 0.01158 & 86 & Eland & 0.00198 & 504 \\
& Blue duiker & 0.12698 & 8 & & & \\
& & & & & &
\end{tabular}

The advantages and disadvantages of using the LSU approach to estimate stocking rates, is discussed in some detail by Boshoff et al. (2001b) and Boshoff et al. (2002). We contend that the LSU-based approach is appropriate for estimating densities of medium to large-sized wild mammals at a mega-reserve (e.g., GAENP) scale, and that realistic values, that can be used for systematic conservation planning in the GAENP planning domain, have been generated. An alternative to the LSU approach for calculating stocking rates is the use of a standing crop biomass of animals as an index of carrying capacity. In savanna regions, often exhibiting high rainfall and nutrient rich soils, primary production and animal density are generally positively correlated with mean annual rainfall (Coe et al. 1976). However, soil type influences and further complicates this relationship, even in the savannas, and the biomass of large ungulates can be as much as 20 times lower on nutrient poor soils (Fritz \&
Duncan 1994). The fact that savannas with nutrient rich soils support different kinds of vegetation and also different types and densities of herbivores from those with nutrient poor soils has been emphasised by Bell (1982). Given the high regional variation in rainfall, soil type (ranging from nutrient poor to nutrient rich soils) and presumably primary productivity, in the GAENP planning domain, this approach was not attempted in the present study.

There is strong evidence that a high density of elephants in the "Addo bush" habitat (Spekboomveld MHC) has a negative impact on the cover, architecture and diversity of the plants (Barratt \& Hall-Martin 1991; Johnson et al. 1999; Lombard et al. 2001; Moolman \& Cowling 1994; Penzhorn et al. 1974; Stuart-Hill 1992; Stuart-Hill \& Aucamp 1993), summarised in Cowling \& Kerley (2002). The only published recommended density for elephant in the AENP, and specifically 


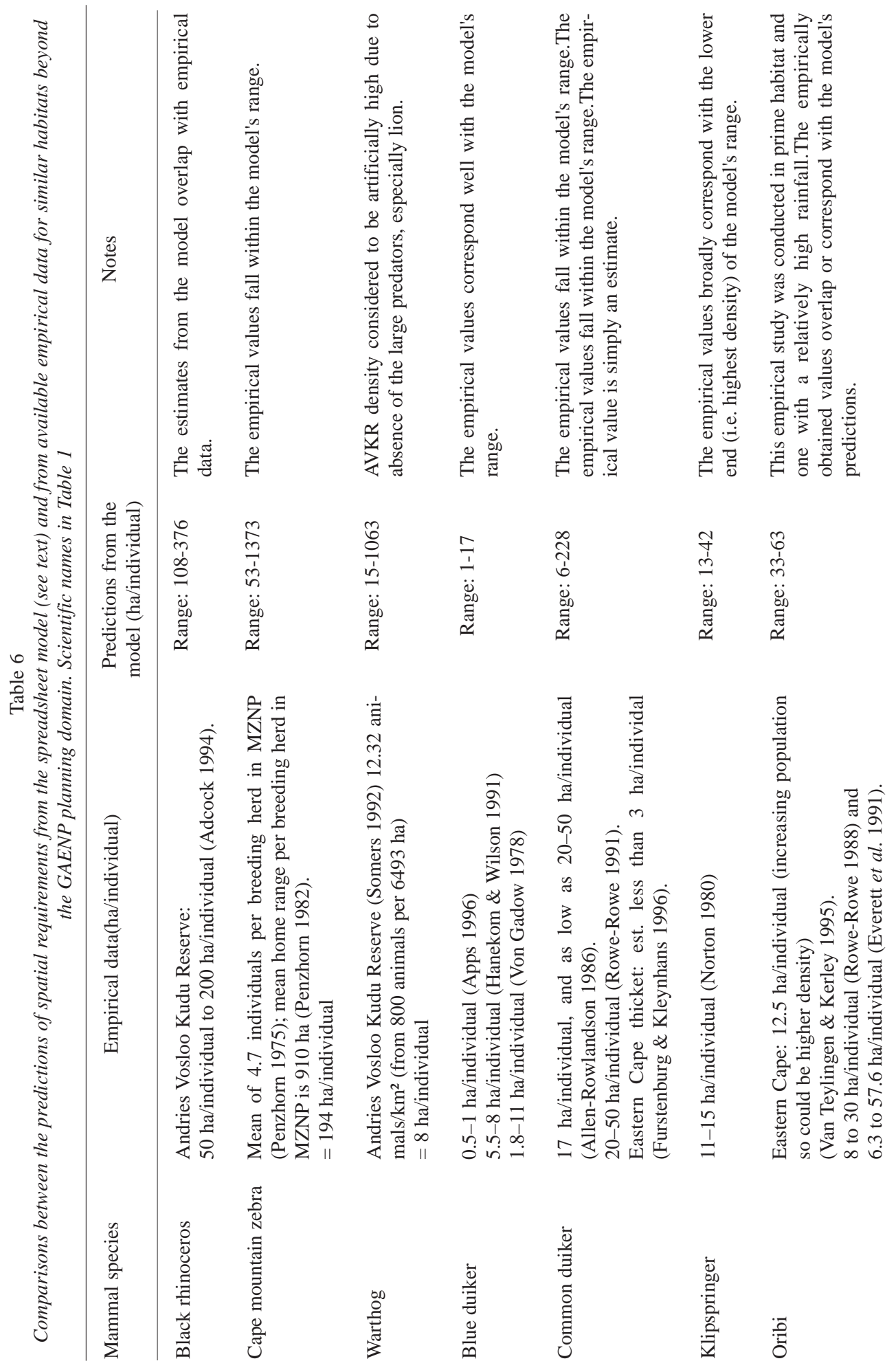



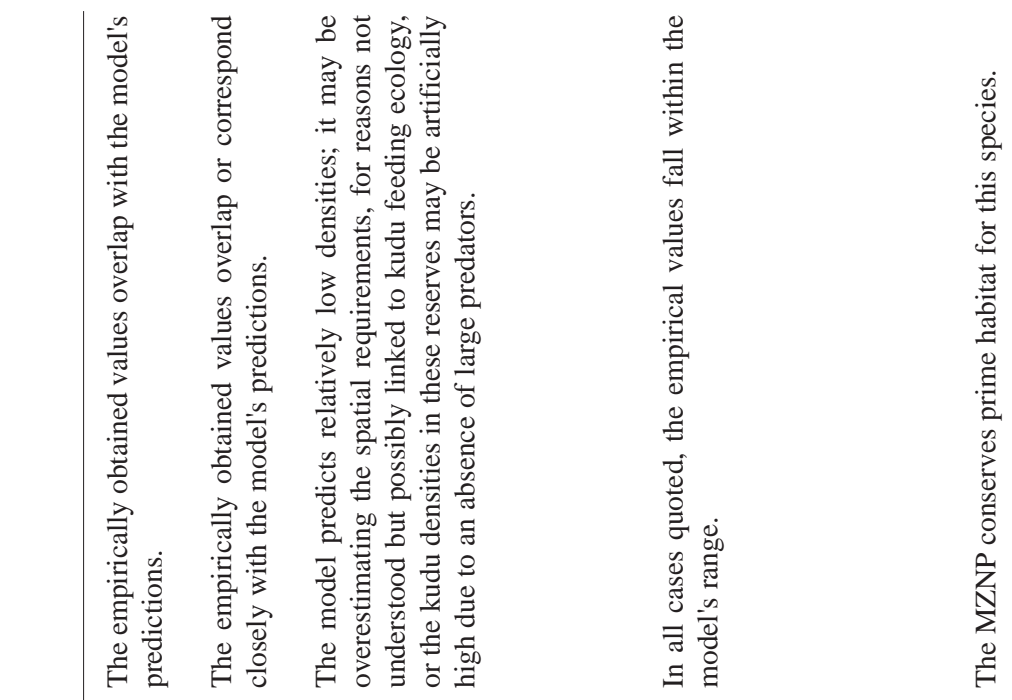

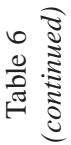

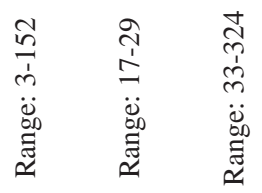

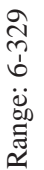

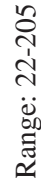

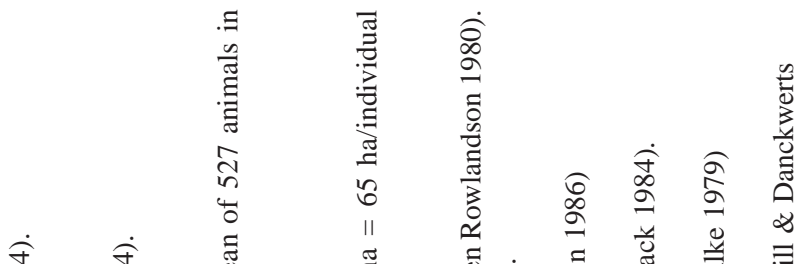

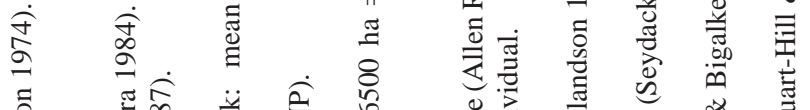

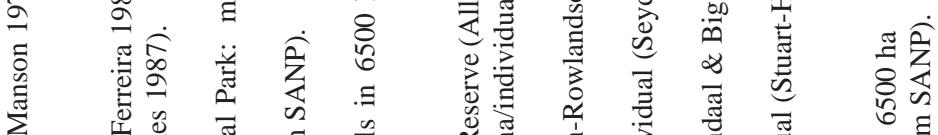

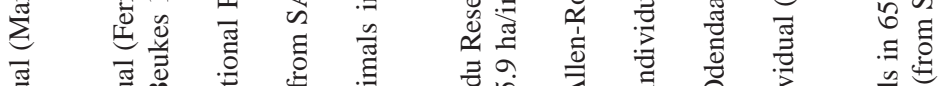

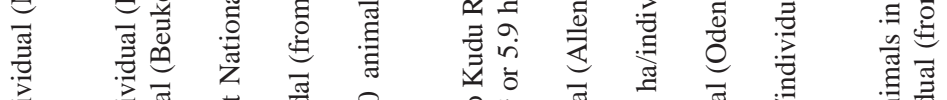

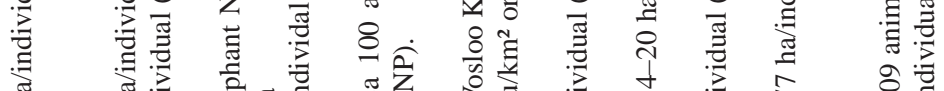

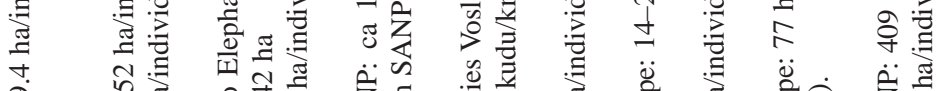

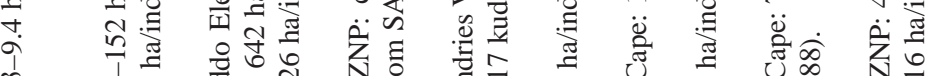

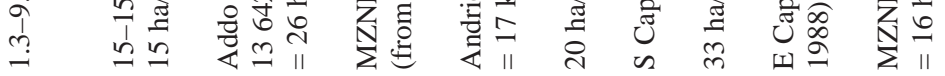

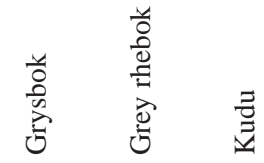

蒙

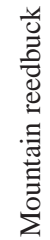



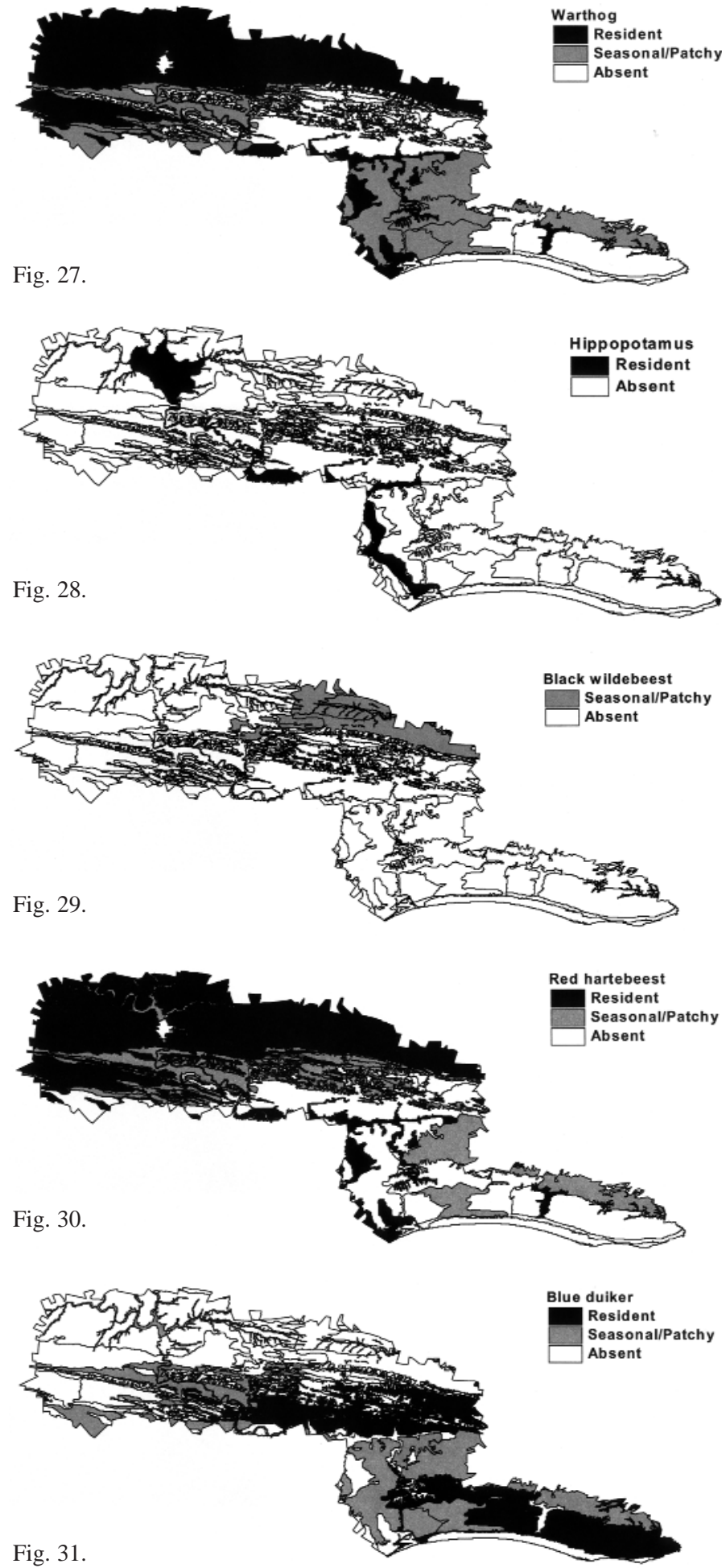

for the Spekboomveld habitat class, is derived from research by National Parks scientists during the early 1970s, when a density of 0.4 elephants per $\mathrm{km}^{2}$ was proposed (Penzhorn et al. 1974). A significantly lower density of 0.142 elephants per $\mathrm{km}^{2}$ was estimated for this habitat by our spreadsheet model. The highest densities predicted by the model, namely 0.54 elephants $/ \mathrm{km}^{2}$, are for the Thicket Forest Mosaic and the Thicket Savanna Mosaic. The basis for the fourfold higher density of 2 elephants $/ \mathrm{km}^{2}$ recommended by Hall-Martin \& Barratt (1991), and adopted by Knight et al. (2002), is questionable (Cowling \& Kerley 2002).

It needs to be emphasised that even though the model has attempted to address the issue of seasonality for certain species (by reducing the amount of allocated forage), it is important that the GAENP be managed as a single spatial unit, in order to provide maximum opportunity for movements by nomadic or migratory species, on a yearround basis. This will cater for ecological factors such as presence of surface water, seasonal food availability and the possible negative effects of selective foraging on threatened plants.

\section{Population sizes}

\section{Methods}

The potential population sizes of the 44 mammal species were calculated by simply multiplying the density estimate for each species with the area (in hectares) of the terrestrial habitats (i.e., MHCs), or length $(\mathrm{km})$, in the case of rivers or coastline. 
These data were calculated for two park planning scenarios, namely: slightly modified Kerley \& Boshoff (1997) planning domain; and the GAENP planning domain; and according to two habitat transformation categories, namely: "Intact" and "Restorable”.

Box 2: Estimated population sizes of the two otter species

Based on the information given in Table 3, it was decided to use a linear density of 1 individual $/ 3 \mathrm{~km}$ of river or coastal habitat for both species of otter, namely Cape clawless otter and spotted-necked otter. Note that the transformation of landscapes did not affect the availability of rivers for otter conservation, i.e., all rivers were considered as "intact" habitat for otters. See "Spacial Requirements" for an explanation of methodology followed.

Cape clawless otter

$183 \mathrm{~km}$ of potentially suitable river and coastal habitat for Cape clawless otter alone $=61$ individuals

$342 \mathrm{~km}$ of potentially suitable river habitat equally shared with spottednecked otter; results in $171 \mathrm{~km}$ available for Cape clawless otter $=57$ individuals.

Grand total $=118$ individuals

Spotted-necked otter

$342 \mathrm{~km}$ of potentially suitable river habitat equally shared with Cape clawless otter; results in $171 \mathrm{~km}$ available for spotted-necked otter $=57$ individuals.

Grand total $=57$ individuals
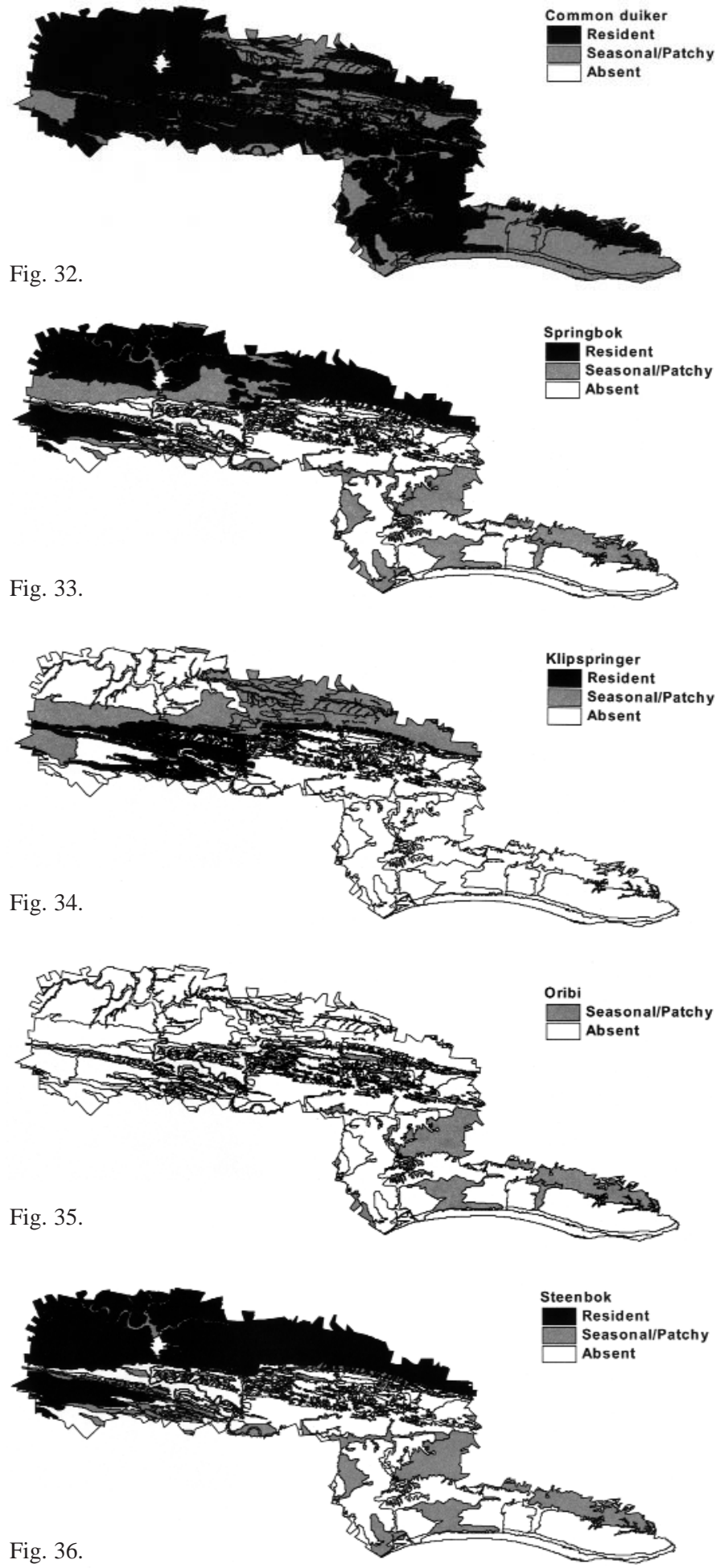

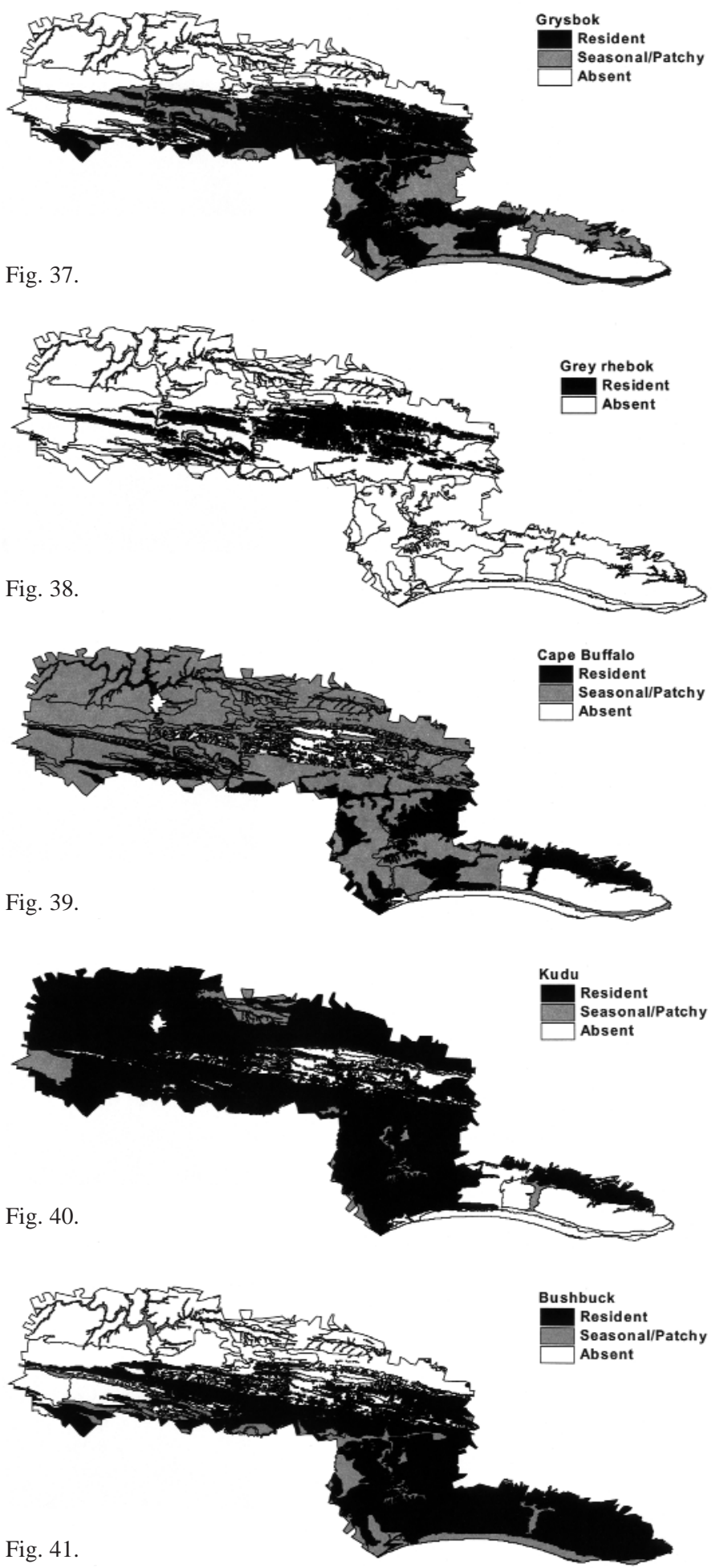

Koedoe 45/2 (2002)

\section{Results}

The potential population sizes, according to two park planning domain scenarios are listed for all species in Table 7. The population estimates for the two otter species are presented in Box 2.

\section{Discussion}

The estimates of populations sizes provided in Table 7 and in Box 2, can be used to measure the degree to which mammal population targets, that are set as part of a separate conservation planning exercise (e.g., Kerley et al. in prep.), are met by the various planning domain scenarios, taking into account different transformation categories.

The estimated population sizes for two species require comment. First, the estimates for the klipspringer require closer scrutiny, as the values appear to be somewhat high. In the MHCs where this species has been marked as being "resident" it may be more appropriate, in a future study, to map individual habitat patches. Second, the estimates for the kudu may be too low. The reasons for this are not known but may be linked with this species' particular feeding ecology. A similar pattern was observed in the analysis for the Cape Floristic Region (Boshoff et al. 2002). The estimates for some of the other smaller ungulates may at face value also appear to be high (e.g., grysbok: JG Castley pers. comm.). We again emphasise that the model's outputs represent potential densities in intact habitats, and 
Table 7

The estimated potential total population sizes of the medium- to large-sized mammals, according to two GAENP planning domain scenarios, and according to two transformation categories.

Scientific names in Table 1

\begin{tabular}{|c|c|c|c|c|c|c|}
\hline \multirow{3}{*}{ Species } & \multicolumn{6}{|c|}{ Estimated number of animals } \\
\hline & \multicolumn{3}{|c|}{$\begin{array}{l}\text { Modified Kerley \& Boshoff (1997) } \\
\text { planning domain }\end{array}$} & \multicolumn{3}{|c|}{ GAENP planning domain } \\
\hline & Intact & Restorable & Total & Intact & Restorable & Total \\
\hline Chacma baboon & 3885 & 1504 & 5388 & 5477 & 2233 & 7710 \\
\hline Vervet monkey & 60440 & 28480 & 88920 & 90504 & 46297 & 136801 \\
\hline Porcupine & 15915 & 6328 & 22242 & 22957 & 10250 & 33207 \\
\hline Aardwolf & 356 & 134 & 490 & 536 & 227 & 763 \\
\hline Brown hyaena & 37 & 15 & 52 & 55 & 24 & 79 \\
\hline Spotted hyaena & 37 & 17 & 55 & 56 & 28 & 84 \\
\hline Cheetah & 3 & 3 & 6 & 6 & 4 & 10 \\
\hline Leopard & 25 & 10 & 36 & 37 & 16 & 53 \\
\hline Lion & 40 & 19 & 58 & 60 & 30 & 90 \\
\hline Caracal & 85 & 36 & 121 & 126 & 59 & 184 \\
\hline African wild cat & 1696 & 720 & 2416 & 2554 & 1189 & 3743 \\
\hline Small spotted cat & 130 & 83 & 213 & 205 & 129 & 334 \\
\hline Serval & 36 & 18 & 54 & 49 & 28 & 78 \\
\hline Bat-eared fox & 3280 & 2137 & 5416 & 5291 & 3472 & 8763 \\
\hline Wild dog & 35 & 15 & 50 & 52 & 25 & 77 \\
\hline Cape fox & 282 & 177 & 458 & 448 & 282 & 731 \\
\hline Black-backed jackal & 418 & 176 & 594 & 619 & 287 & 907 \\
\hline Honey badger & 48 & 19 & 67 & 70 & 31 & 101 \\
\hline Aardvark & 45 & 23 & 68 & 70 & 38 & 108 \\
\hline African elephant & 322 & 141 & 464 & 523 & 248 & 771 \\
\hline Black rhinoceros & 766 & 401 & 1167 & 1250 & 677 & 1927 \\
\hline Cape mountain zebra & 851 & 161 & 1012 & 1083 & 245 & 1328 \\
\hline Burchell’s zebra & 996 & 805 & 1801 & 1724 & 1324 & 3048 \\
\hline Bushpig & 3316 & 958 & 4274 & 4845 & 1557 & 6402 \\
\hline Warthog & 1325 & 820 & 2145 & 2206 & 1362 & 3569 \\
\hline Hippopotamus & 27 & 29 & 55 & 32 & 33 & 64 \\
\hline Black wildebeest & 24 & 8 & 32 & 43 & 21 & 64 \\
\hline Red hartebeest & 874 & 460 & 1334 & 1369 & 755 & 2124 \\
\hline Blue duiker & 24849 & 7824 & 32673 & 36277 & 12352 & 48628 \\
\hline Common duiker & 14479 & 6843 & 21322 & 21777 & 11204 & 32981 \\
\hline Springbok & 1666 & 1022 & 2689 & 2929 & 1815 & 4744 \\
\hline Klipspringer & 3574 & 1293 & 4867 & 4836 & 1954 & 6790 \\
\hline Oribi & 702 & 510 & 1213 & 1234 & 929 & 2162 \\
\hline Steenbok & 7967 & 6213 & 14181 & 13288 & 9958 & 23246 \\
\hline Grysbok & 21964 & 3693 & 25657 & 28569 & 6296 & 34865 \\
\hline Grey rhebok & 2122 & 88 & 2210 & 2393 & 106 & 2499 \\
\hline Cape buffalo & 582 & 414 & 996 & 1058 & 732 & 1789 \\
\hline Kudu & 2023 & 1120 & 3143 & 3277 & 1892 & 5169 \\
\hline Bushbuck & 7684 & 2965 & 10649 & 11577 & 5074 & 16652 \\
\hline Eland & 340 & 84 & 424 & 470 & 144 & 614 \\
\hline Reedbuck & 103 & 128 & 231 & 219 & 241 & 460 \\
\hline Mountain reedbuck & 1528 & 423 & 1951 & 1980 & 639 & 2618 \\
\hline
\end{tabular}



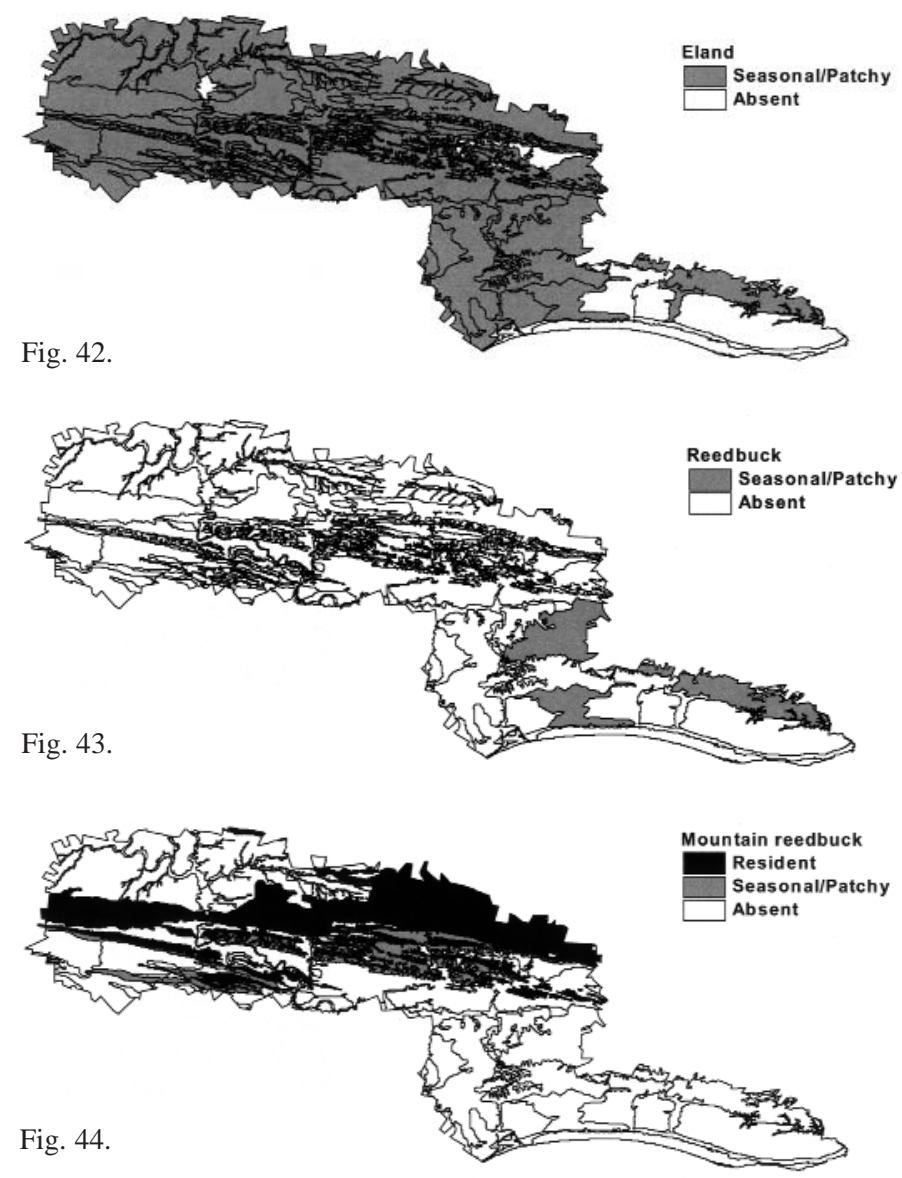

therefore cannot be equated with current densities in transformed habitats.

The data in Table 7 indicate that potential populations of herbivore species that are more prevalent in the "upland" areas are less impacted by transformed (but potentially restorable) habitats than are herbivore species that are more prevalent in "lowland" areas. For example, the steenbok is markedly affected by transformation in the "lowland" areas, whereas the grey rhebok is not. This pattern is understandable, given that most of the transformation has occurred in the "lowland" areas.

\section{GENERAL DISCUSSION}

The information generated by the present study provides realistic guidelines for the testing of population targets for medium to large-sized mammals that can potentially occur in the GAENP planning domain, and for the identification of species for which metapopulation management may be required for their conservation. It will also guide park managers regarding species that are no longer present in the general GAENP domain but that can be considered for reintroduction, and in the maintenance of realistic densities. The information in this report 
will therefore make a significant contribution to achieving the overall conservation goals of the GAENP.

It is important that the estimates derived by this study be treated as hypothetical guidelines at this stage. Thus, any management action based on these estimates should be considered experimental, should be tested through adaptive management strategies and should be closely monitored. The need to test indigenous herbivore spatial requirement/density estimates in practice, and to adapt them in the light of field experience, has been mentioned elsewhere (Trollope 1990). In addition, the final stocking rates for these herbivores should be conservative, in order to cope with unfavourable conditions (Trollope 1990). We thus advocate a "management by hypothesis" approach, with assumptions and predictions being explicitly tested. A major advantage of the estimates presented here is that the assumptions are explicitly quantitative and can be modified as these ideas are tested, allowing adaptive management principles and actions to be employed. The concepts of "management by hypothesis" and "adaptive management" are a generally accepted approach to dealing with management challenges associated with a paucity of information (Bowman 1995; Macnab 1983; May 1991).

\section{Acknowledgements}

We are grateful to the following persons for providing insights, information and assistance in the development of this report: Rebecca Sims-Castley (TERU, University of Port Elizabeth); Amanda Lombard (Conservation Systems, Knysna); Mike Knight, Guy Castley, Lucius Moolman, John Adendorff (South African National Parks); Lloyd Wingate and Fred Kigozi (Amatole Museum, King William's Town). Guy Castley provided additional valuable comments on a draft of this paper.

The GIS tasks involved in collapsing the 43 original land classes to form 21 Mammal Habitat Classes (MHC), and the calculation of the areas of the MHCs that comprised, or did not comprise, habitat for hippopotamus, and also the areas of "Intact" and "Restorable" habitat, were conducted by CSIR-
Environmentek, in a consortium with TERU, as part of a GEF co-funded contract to South African Parks to provide conservation planning services. We thank Jeanne Nel, Inge Kotze, Sarah Davies and Dirk Roux, all of CSIR-Environmentek, for their patience and co-operation in providing TERU with these GIS outputs.

South African National Parks is thanked for permission to publish this material.

\section{References}

AdсосK, K. 1994. The relevance of "territorial" behaviour in black rhino to their population management. Pp. 82-86. In: Penzhorn, B.L. \& N.P.J. Kriel (eds.). Proceedings of a Symposium on Rhinos as Game Ranch Animals. Pretoria: Onderstepoort.

ALLen-Rowlandson, T.S. 1980. The social and spatial organisation of the greater kudu (Tragelaphus strepsiceros Pallas, 1766) in the Andries Vosloo Kudu Reserve, Eastern Cape. MSc dissertation, Rhodes University, Grahamstown.

AlLEN-Rowlandson, T.S. 1986. An autecological study of bushbuck and common duiker in relation to forest management. Ph.D. thesis, Universtity of Natal, Pietermaritzburg.

Anonymous, 1985. The National Grazing Strategy. Pretoria: Department of Agriculture.

Apps, P. 1996. Smithers' Mammals of southern Africa: a field guide. Halfway House: Southern Book Publishers.

BarratT, D.G. \& A. Hall-Martin. 1991. The effect of indigenous browsers on valley bushveld in the Addo Elephant National Park. Pp. 14-16. In: Zacharias, P.J.K., G.C. Stuart-Hill \& J. Midgley (eds.). Proceedings of the First Valley Bushveld Symposium. Grassland Society of South Africa. Howick.

BELL, R.H.V. 1982. The effect of soil nutrient availability on community structure in African ecosystems. Pp. 193-216. In: Huntley, B.J. \& B.H. WALKER (eds.). Ecology of tropical savannas. Berlin: Springer-Verlag.

BeuKes, P.C. 1987. Responses of grey rhebuck and bontebok to controlled fires in coastal renosterveld. South African Journal of Wildlife Research 17: 103-108.

Boshoff, A.F. \& G.I.H. Kerley. 2001. Potential distributions of the medium- to large-sized mammals of the Cape Floristic Region based on historical accounts and habitat requirements. African Zoology 36: 245-273.

Boshoff, A.F., G.I.H. KerLey, R.M. COWLING \& S.L. WILSON. 2001a. Conservation planning in the Greater Addo National Park: a review of the species-, population- and spatially-driven 
processes involving the medium- to large-sized mammals. Terrestrial Ecology Research Unit (University of Port Elizabeth), Report No. 34.

Boshoff, A.F., G.I.H. Kerley \& R.M. Cowling. 2001b. A pragmatic approach to estimating the distributions and spatial requirements of the medium- to large-sized mammals in the Cape floristic region, based on historical accounts and habitat requirements. Diversity and Distributions 7: 29-43.

Boshoff, A.F., G.I.H. Kerley \& R.M. Cowling. 2002. Estimated spatial requirements of the medium- to large-sized mammals, according to Broad Habitat Units, in the Cape Floristic Region, South Africa. African Journal of Range and Forage Science 19: 27-42.

Bowman, D. 1995. Down in the forest something stirred. New Scientist (9 December) 2007: 54.

Butterfield, B.R., B. Csuti \& J.M. SCott. 1994. Modeling vertebrate distributions for Gap Analysis. Pp. 53-68. In: Miller, R.I. (ed.). Mapping the Diversity of Nature. London: Chapman \& Hall.

CAmpBell, B.M. 1986. Plant spinescence and herbivory in a nutrient-poor ecosystem. Oikos 47: 168-172.

CAstley, J.G., A.F. Boshoff \& G.I.H. KerLey. 2001. Compromising South Africa's natural biodiversity-inappropriate herbivore introductions. South African Journal of Science 97: 344-348.

Caughley, G. 1994. Directions in conservation biology. Journal of Animal Ecology 63: 215-244.

CAUGHLEY, G. \& A.R.E. SinClaiR. 1994. Wildlife ecology and management. London: Blackwell Science.

CHEw, R.M. 1978. The impact of small mammals on ecosystem structure and function. Pp. 167-180. In: SNyder, D.P. (ed.) Pymatuning symposium on populations of small mammals under natural conditions. Vol. 5. Spec. Publ. Ser. Pymatuning Laboratory of Ecology. University of Pittsburgh.

Coe, M.J., D.M. Cumming \& J. Phillipson. 1976. Biomass and production of large African herbivores in relation to rainfall and primary production. Oecologia 22: 341-354.

CoetZee, P.W. 1979. Present distributions and status of some of the mammals of Albany. Grahamstown: Albany Divisional Council.

Collinson, R.F.H. \& P.S. GoOdman. 1982. An assessment of range conditions and large herbivore carrying capacity of the Pilanesberg Game Reserve, with guidelines and recommendations for management. Inkwe 1: 1-55.

Cowling, R.M. \& G.I.H. KerLeY. 2002. Impacts of elephants on the flora and vegetation of subtropical thicket in the Eastern Cape. Pp. 55-72. In: Kerley, G.I.H., S.L. Wilson \& A. MAssey (eds.). Elephant conservation and management in the Eastern Cape: Workshop Proceedings.
Terrestrial Ecology Research Unit (University of Port Elizabeth) Report No. 35:

Devore, I. \& K.R.L. HALL. 1965. Baboon ecology. In: De Vore, I. (ed.) Primate behaviour: field studies of monkeys and apes. New York: Holt, Rinehart \& Winston.

Du Plessis, S.F. 1969. The past and present geographical distribution of the Perissodactyla and Artiodactyla in southern Africa. M.Sc. Thesis, University of Pretoria, Pretoria.

Everett, P.S., M.R. Perrin \& D.T. Rowe-Rowe. 1991. Responses by oribi to different range management practises. South African Journal of Wildlife Research 21:114-118.

FERreirA, N.A. 1984. Various aspects of the ecology of the grey rhebuck. Pelea 3: 7-13.

Fritz, H. \& P. Duncan. 1994. On the carrying capacity for large ungulates of African savanna ecosystems. Proceedings of the Royal Society, London 256: 77-82.

FurstenburG, D. \& M. KLeynhans. 1996. Kudu and bushbuck in boergoat production systems in Valley Bushveld: ecological interactions and constraints. Pelea 15:5-13.

Grossman, D. 1991. Carrying capacity, game numbers and optimal utilisation. Seminar: Game Ranch Management. Potchefstroom: Potchefstroom University.

Hall-Martin, A.J. \& D.G. Barratt. 1991. The effect of elephants Loxodonta africana on thicket vegetation in the Addo Elephant National Park. Internal Report, South African National Parks, Pretoria.

Hall-Martin, A.J. \& M.H. Knight. 1994. Conservation and management of black rhinoceros in South African national parks. Pp. 11-19. In: Penzhorn, B.L. \& N.P.J. KRIEL (eds.). Proceedings of a Symposium on Rhinos as Game Ranch Animals. Pretoria: Onderstepoort.

HaneKom, N. \& V. Wilson. 1991. Blue duiker Philantomba monticola densities in the Tsitsikamma National Park, and probable factors limiting these populations. Koedoe 34: 107-120.

HewitT, J. 1931. A guide to the vertebrate fauna of the Eastern Cape Province. Grahamstown: Albany Museum.

Johnson, S.D. 1992. Plant-animal relationships. Pp. 175-205. In: Cowling, R.M. (ed.) The ecology of fynbos: nutrients, fire and diversity. Cape Town: Oxford University Press.

Johnson, C.F., R.M. Cowling \& P.B. Phillipson. 1999. The flora of the Addo Elephant National Park, South Africa: are threatened species vulnerable to elephant damage. Biodiversity and Conservation 8: 1447-1456.

Kerley, G.I.H. \& A.F. Boshoff. 1997. A proposal for a Greater Addo National Park: a regional and national conservation and development opportu- 
nity. Terrestrial Ecology Research Unit, University of Port Elizabeth; (internal report no. 17).

Kerley, G.I.H. \& A.F. Boshoff. 2002. The Greater Addo National Park Initiative: linking biodiversity to socio-economic development. Pp. 57-66. In: Pierce, S.M., R.M Cowling, \& T. SAndWITH. (eds.). Mainstreaming biodiversity in development: case studies from South Africa. Washington, DC: International Bank for Reconstruction and Development/The World Bank.

Knight, M., G. Castley, L. Moolman \& J. AdenDORFF. 2002. Elephant management in Addo Elephant National Park. Pp. 32-40. In: KerLey, G.I.H., S.L. WiLson \& A. MASSEY (eds.). Elephant conservation and management in the Eastern Cape: Workshop Proceedings. (Terrestrial Ecology Research Unit, University of Port Elizabeth; internal report no. 35).

Kruger, L. \& C. Sykes. 2002. Field mapping of land classes and land transformation. Pp. 218262. In: Conservation Planning Framework for the Greater Addo Elephant National Park (Part 1) - Final (internal) Report. South African National Parks.

Lande, R. \& G.F. Barrowclough. 1987. Effective population size, genetic variation, and their use in population management. Pp. 87-123. In: Soulé, M.E. (ed.). Viable populations for conservation. Cambridge: Cambridge University Press.

LLOYD, P.H. \& J.C.G. MilLAR. 1983. A questionnaire survey (1969-1974) of some of the larger mammals of the Cape Province. Bontebok 3: 1-49.

Lombard, A.T., C.F. Johnson, R.M. Cowling \& R.L. Pressey. 2001. Protecting plants from elephants: botanical reserve scenarios within the Addo Elephant National Park, South Africa. Biological Conservation. 102: 191-203.

Low, A. B. \& A. G. Rebelo. 1996. Vegetation of South Africa, Lesotho and Swaziland. Pretoria: Department of Environmental Affairs \& Tourism.

MACDONALD, I.A.W. 1992. Vertebrate populations as indicators of change in southern Africa. Transactions of the Royal Society of South Africa 48: 87-122.

MACNAB, J. 1983. Wildlife management as scientific experimentation. Wildlife Society Bulletin 11: 397-401.

Manson, J. 1974. Aspekte van die biologie en gedrag van die Kaapse grysbok Raphicerus melanotis. M.Sc. dissertation. University of Stellenbosch. Stellenbosch.

MAY, R.M. 1991. The role of ecological theory in planning re-introduction of endangered species. Symposium of the Zoological Society of London 62: 145-163.

MeIssneR, H.H. 1982. Theory and application of a method to calculate forage intake of wild south- ern African ungulates for purposes of estimating carrying capacity. South African Journal of Wildlife Research 12: 41-47.

Moen, A.N. 1973. Wildlife Ecology. San Francisco: Freeman.

Moolman, H.J. \& R.M. Cowling. 1994. The impact of elephant and goat grazing on the endemic flora of South African succulent thicket. Biological Conservation 68: 53-61.

Morris, C.D., M.B. Hardy \& P.E. Bartholomew. 1999. Stocking rate. Pp. 186-193. In: TAINTON, N. (ed.). Veld management in South Africa. Pietermaritzburg: University of Natal Press.

NoRTON, P.M. 1980. The habitat and feeding ecology of the klipspringer Oreotragus oreotragus in two areas of the Cape Province. M.Sc. dissertation. University of Pretoria. Pretoria.

OdendaAl, P.B. \& R.C. Bigalke. 1979. Home range and groupings of bushbuck in the southern Cape. South African Journal of Wildlife Research 9:96101.

PenzhoRn, B.L. 1975. Behaviour and population ecology of the Cape mountain zebra in the Mountain Zebra National Park. D.Sc. thesis. University of Pretoria.

Penzhorn, B.L. 1982. Home range sizes of Cape mountain zebras Equus zebra zebra in the Mountain Zebra National Park. Koedoe 25: 103108.

Penzhorn, B.L., P.J. Robbertse \& M.C. Olivier. 1974. The influence of the African elephant on the vegetation of the Addo Elephant National Park. Koedoe 17: 137-158.

ROOKMAAKeR, L.C. 1989. The zoological exploration of southern Africa 1650-1790. Rotterdam: Balkema.

Rowe-Rowe, D.T. 1988. Oribi - Natal's most threatened antelope. Pietermaritzburg: Natal Parks Board. (Wildlife Management Technical Guides for Farmers no. 20.)

Rowe-Rowe, D.T. 1991. The ungulates of Natal. Pietermaritzburg: Natal Parks Board.

SEYDACK, A.H.W. 1984. Application of a photorecording device in the census of larger rain-forest mammals. South African Journal of Wildlife Research 14: 10-14.

SHORTRIDGE, G.C. 1942. Field notes on the first and second expeditions of the Cape Museums mammal survey of the Cape Province and descriptions of some new subgenera and species. Annals of the South African Museum 36: 27-100.

SKEAD, C.J. 1987. Historical mammal incidence in the Cape Province: Vol. 2 - The eastern half of the Cape Province, including the Ciskei, Transkei and East Griqualand. Cape Town: Dept Nature \& Environmental Conservation.

SKInNER, J.D. \& R.H.N. SMITHERS. 1990. The mammals of the southern African subregion. Pretoria: University of Pretoria. 
Smithers, R.H.N. 1986. South African red data book: terrestrial mammals. Pretoria: Council for Scientific and Industrial Research, National Scientific Programmes Unit. (South African National Science Programmes report; no. 125).

Somers, M. 1992. The implications of social structure for the conservation and control of a warthog Phacochoerus aethiopicus population in the Andries Vosloo Kudu Reserve, Eastern Cape province. M.Sc. dissertation. University of Pretoria, Pretoria.

Soulé, M. (ed.) 1987. Viable populations for conservation. Cambridge: Cambridge University Press.

StUART, C.T. 1981. Notes on the mammalian carnivores of the Cape Province, South Africa. Bontebok 1: 1-58.

STUART, C.T. 1985. The status of two endangered carnivores occurring in the Cape Province, South Africa, Felis serval and Lutra maculicollis. Biological Conservation 32: 375-382.

Stuart-Hill, G. C. 1992. Effects of elephants and goats on the Kaffrarian succulent thicket of the eastern Cape, South Africa. Journal of Applied Ecology 29: 699-710.

Stuart-Hill, G. C. \& A.J. Aucamp. 1993. Carrying capacity of the succulent valley bushveld of the eastern Cape. African Journal of Range and Forage Science 10: 1-10.

StUART-HiLl, G. \& J. DANCKWERTs. 1988. Influence of domestic and wild animals on the future of succulent valley bushveld. Pelea 7: 45-46.

Stuart, C.T., I.A.W. Macdonald \& M.G.L. Mills. 1985. History, current status and conservation of large mammalian predators in Cape Province,
Republic of South Africa. Biological Conservation 31: 7-19.

Trollope, W.S.W. 1990. Veld management with specific reference to game ranching in the grassland and savanna areas of South Africa. Koedoe 33: 77-87.

Van Teylingen, K. \& G.I.H. Kerley. 1995. Habitat characteristics of increasing and decreasing oribi subpopulations in the Eastern Cape Province, South Africa. South African Journal of Wildlife Research 25:118-122.

VLOK, J.H. \& D. Euston-BRown. 2002. Subtropical Thicket Ecosystem Planning (STEP) Project: Biological Survey Report (Plants and birds). Unpublished Report, Terrestrial Ecology Research Unit, University of Port Elizabeth.

Von Gadow, K. 1978. A pellet count of blue duiker and bushbuck in the Knysna forests. South African Forestry Journal 107: 77-81.

WILCOX, B.A. 1982. In situ conservation of genetic resources: determinants of minimum area requirements. Pp. 639-647. In: McNeELy, J.A. \& K.R. Miller (eds.). National parks, conservation and development-the role of protected areas in sustaining society. Washington DC: Smithsonian Institution.

Whitehouse, A.M. \& G.I.H. KerLey. 2002. Retrospective assessment of long-term conservation management of elephants in Addo Elephant National Park, South Africa. Oryx 36: 243-248.

\section{Appendix 1}

Adjusting stocking rates and proportional allocation of stocking opportunities to foraging guilds (see text for methods)

\begin{tabular}{|c|c|c|c|c|c|c|c|c|c|c|c|c|c|c|c|c|c|c|c|c|c|}
\hline & 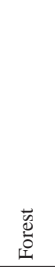 & 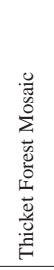 & 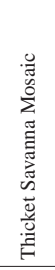 & 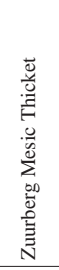 & 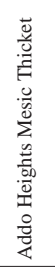 & 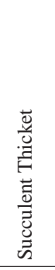 & $\begin{array}{l}\text { च्च } \\
\text { टे } \\
\text { वे } \\
\text { के } \\
\text { के }\end{array}$ & 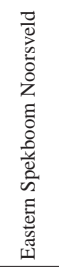 & 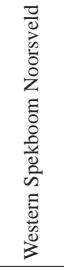 & 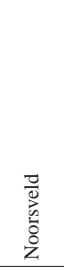 & 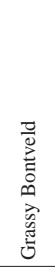 & 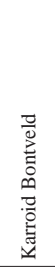 & 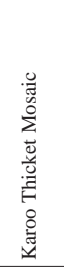 & 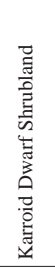 & 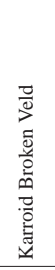 & 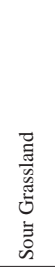 & 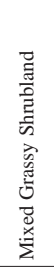 & 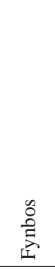 & 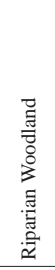 & 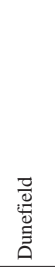 & 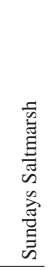 \\
\hline \multicolumn{22}{|l|}{ Adjusted Stocking } \\
\hline Rate (LSU/ha) & 0.017 & 0.111 & 0.143 & 0.059 & 0.059 & 0.048 & 0.045 & 0.056 & 0.045 & 0.042 & 0.056 & 0.056 & 0.042 & 0.042 & 0.048 & 0.050 & 0.059 & 0.048 & 0.143 & 0.004 & 0.00 \\
\hline Bulk Grazer & 1 & 5 & 20 & 9 & 9 & 5 & 5 & 30 & 25 & 25 & 29 & 20 & 15 & 20 & 25 & 30 & 20 & 10 & 30 & 0 & 0 \\
\hline Concentrate Grazer & 1 & 1 & 20 & 1 & 1 & 15 & 10 & 10 & 10 & 10 & 18 & 15 & 15 & 15 & 15 & 30 & 20 & 10 & 15 & 0 & 0 \\
\hline Mixed Feeder & 29 & 27 & 15 & 25 & 25 & 15 & 20 & 10 & 10 & 10 & 18 & 15 & 15 & 15 & 15 & 20 & 20 & 20 & 15 & 20 & 0 \\
\hline Browser & 69 & 67 & 45 & 65 & 65 & 65 & 65 & 50 & 55 & 55 & 35 & 50 & 55 & 50 & 45 & 20 & 40 & 60 & 40 & 80 & 0 \\
\hline
\end{tabular}

